\title{
The Impact of Autoantibodies on IVF Treatment and Outcome: A Systematic Review
}

\author{
Mara Simopoulou ${ }^{1,2, *} \mathbb{0}$, Konstantinos Sfakianoudis ${ }^{3}$, Evangelos Maziotis ${ }^{1}$, \\ Sokratis Grigoriadis 1ํ, Polina Giannelou 1,3 ${ }^{1}$, Anna Rapani ${ }^{1}$, Petroula Tsioulou ${ }^{1}$, Agni Pantou ${ }^{3}$, \\ Theodoros Kalampokas ${ }^{4}$, Nikolaos Vlahos ${ }^{2}$, Konstantinos Pantos ${ }^{3}$ and Michael Koutsilieris ${ }^{1}$ \\ 1 Department of Physiology, Medical School, National and Kapodistrian University of Athens, 75, Mikras \\ Asias, 11527 Athens, Greece; vagmaziotis@gmail.com (E.M.); sokratis-grigoriadis@hotmail.com (S.G.); \\ lina.giannelou@gmail.com (P.G.); rapanianna@gmail.com (A.R.); petroulatsi@yahoo.gr (P.T.); \\ mkoutsil@med.uoa.gr (M.K.) \\ 2 Assisted Conception Unit, 2nd Department of Obstetrics and Gynecology, Aretaieion Hospital, Medical \\ School, National and Kapodistrian University of Athens, 76, Vasilisis Sofias Avenue, 11528 Athens, Greece; \\ gynoffice04@gmail.com \\ 3 Centre for Human Reproduction, Genesis Athens Clinic, 14-16, Papanikoli, 15232 Athens, Greece; \\ sfakianosc@yahoo.gr (K.S.); agnipantos@gmail.com (A.P.); info@pantos.gr (K.P.) \\ 4 Aberdeen Maternity Hospital, Fertility Center-Assisted Reproduction Unit, Aberdeen AB25 2ZL, UK; \\ t.kalampokas@abdn.ac.uk \\ * Correspondence: marasimopoulou@hotmail.com; Tel.: +30-2107462592
}

Received: 31 January 2019; Accepted: 14 February 2019; Published: 19 February 2019

\begin{abstract}
The role of autoantibodies in in vitro fertilization (IVF) has been discussed for almost three decades. Nonetheless, studies are still scarce and widely controversial. The aim of this study is to provide a comprehensive systematic review on the possible complications associated to autoantibodies (AA) impeding the chances of a successful IVF cycle. An Embase, PubMed/Medline and Cochrane Central Database search was performed on 1 December 2018, from 2006 until that date. From the 598 articles yielded in the search only 44 relevant articles ultimately fulfilled the inclusion criteria and were qualitatively analyzed. Five subsets of results were identified, namely, thyroid related AA, anti-phospholipid antibodies, anti-nuclear antibodies, AA affecting the reproductive system and AA related to celiac disease. It may be implied that the majority of auto-antibodies exert a statistically significant effect on miscarriage rates, whereas the effects on clinical pregnancy and live birth rates differ according to the type of auto-antibodies. While significant research is performed in the field, the quality of evidence provided is still low. The conduction of well-designed prospective cohort studies is an absolute necessity in order to define the impact of the different types of autoantibodies on IVF outcome.
\end{abstract}

Keywords: auto-antibodies; autoimmune disorders; assisted reproduction; in vitro fertilization

\section{Introduction}

The evolution of assisted reproductive technologies (ART) from classic in vitro fertilization (IVF) [1] and intracytoplasmic sperm injection (ICSI) [2] to the era of prediction models employing artificial intelligence [3] over the past years has encouraged a worldwide reproductive revolution. The etiology of infertility is thought to be multifactorial with some of the key aspects being genetic abnormalities of equally male and female origin, ovulatory disorders, tubal obstructions, uterine, or peritoneal issues linked to female infertility and male factor associated with poor sperm quality [4]. In 2018 the European Society of Human Reproduction and Embryology (ESHRE) reported that 20-30\% of infertility cases are attributed to physiological causes in men, 20-35\% to female etiology, and $25-40 \%$ 
are related to both female and male factor infertility. The remaining $10-20 \%$ of infertility cases [5] are categorized as unexplained or idiopathic cases and most of these couples suffer from recurrent implantation failure (RIF). Despite ART's remarkable development there is still a significant percentage of failed IVF attempts. Numerous existing reports have focused on various factors, from uterine anatomy and endometrium receptivity, to connective tissue disorders and several immunologic factors, impacting negatively or positively the success rates of IVF treatments [6,7].

The process of implantation represents a critical step involving the interaction between the embryo and uterine epithelium [8]. During implantation two immunologically and genetically distinct tissues are challenged into achieving successful communication. In the current bibliography, several autoimmune factors have been associated with implantation failure outcomes [8-10]. In order to investigate reproductive failure, certain studies focused on associations between the autoimmune system and the IVF/ICSI outcome highlighting the role of autoantibodies during treatment $[8,11]$. Furthermore, recently it has been suggested that autoimmune diseases, such as systematic lupus, erythematosus, and anti-phospholipid syndrome, play a crucial role in infertility and its management. This relationship is established either through a direct association between autoimmune disorders, compromising an otherwise good fertility status, or autoimmune disorders adding another level of complexity to an existing poor fertility status.

Interestingly, the levels of antiphospholipid antibodies (APL), antinuclear antibodies (ANA), or thyroid auto-antibodies (TAA) appear to be significantly increased in women diagnosed with unexplained infertility. Additionally, serum auto-antibodies are associated with early ovarian failure thus their contribution to infertility remains a topic of a heated debate $[10,11]$. Furthermore, anti-sperm antibodies are more often associated with fertilization failure when found in high titers in seminal plasma [8]. The role of autoantibodies in IVF has been debated for almost three decades and still global literature lacks the clinical evidence in order to delineate their role in infertility and standardize respective management. With practitioners facing conundrums in managing infertility where autoimmune antibodies are involved, and the lack of universal protocols recruited to overcome complex cases in the spectrum of autoimmune disorders, it is imperative for the scientific community to pursue the search for the holy-grail in understanding and subsequently successfully treating these multifaceted cases.

The aim of this study is to extract evidence-based data from current published literature in order to provide information pertaining to the patients' performance that may be anticipated following IVF treatment in relation to the presence of autoimmune antibodies. Herein a systematic review attempts to provide a comprehensive analysis on the possible associations of autoantibodies in regards to a successful IVF cycle. The analysis revolves around the most prevalent groups of autoantibodies that have been reported to affect the reproductive system including thyroid autoantibodies, antiphospholipid autoantibodies, antinuclear autoantibodies, antisperm, antiendometrial, antigonadotropin autoantibodies, and autoantibodies causing celiac disease. Respective associations in regards to IVF outcome and conclusions pertaining to subsequent management constitute the driver of this work.

\section{Materials and Methods}

\subsection{Search Strategy}

A systematic search of the literature was performed in Pubmed/Medline, Embase, and Cochrane Central databases on the 1 December 2018, from 2006 until that date (Supplementary Materials). The keywords employed and combined for the search strategy were: "In-Vitro Fertilization", "IVF", "Assisted Reproduction", "Assisted Reproduction Techniques", "Medical Assisted Reproduction", "Intracytoplasmic Sperm Injection", "ICSI", "auto-antibodies", "antibodies", "anti-sperm", "antinuclear antibodies", "anti-thyroid antibodies", "autoimmune disorders", "autoimmunity". The original search yielded 598 studies from the three databases. Following the removal of duplicate studies $(n=9)$, all records were screened and full-text was sought and obtained 
for relevant articles. Relevant articles $(n=53)$, were identified following title and abstract screening, employing the flow chart of Preferred Reporting Items for Systematic Reviews and Meta-analysis (PRISMA) as presented in Figure 1. Screening and selection of literature was performed independently by three authors. Disagreements between the authors were resolved by an arbitration mediated by the senior authors. Citation mining was performed where the reference lists of all included articles and relevant reviews and metanalyses were reviewed to identify other articles of relevance. The search was limited to full-length manuscripts published in English in peer-reviewed journals up to December 2018. A total of 44 studies were included in the present systematic review. No protocol was submitted to the Prospero International Prospective Register of Systematic Reviews, providing details on conducting of this study.

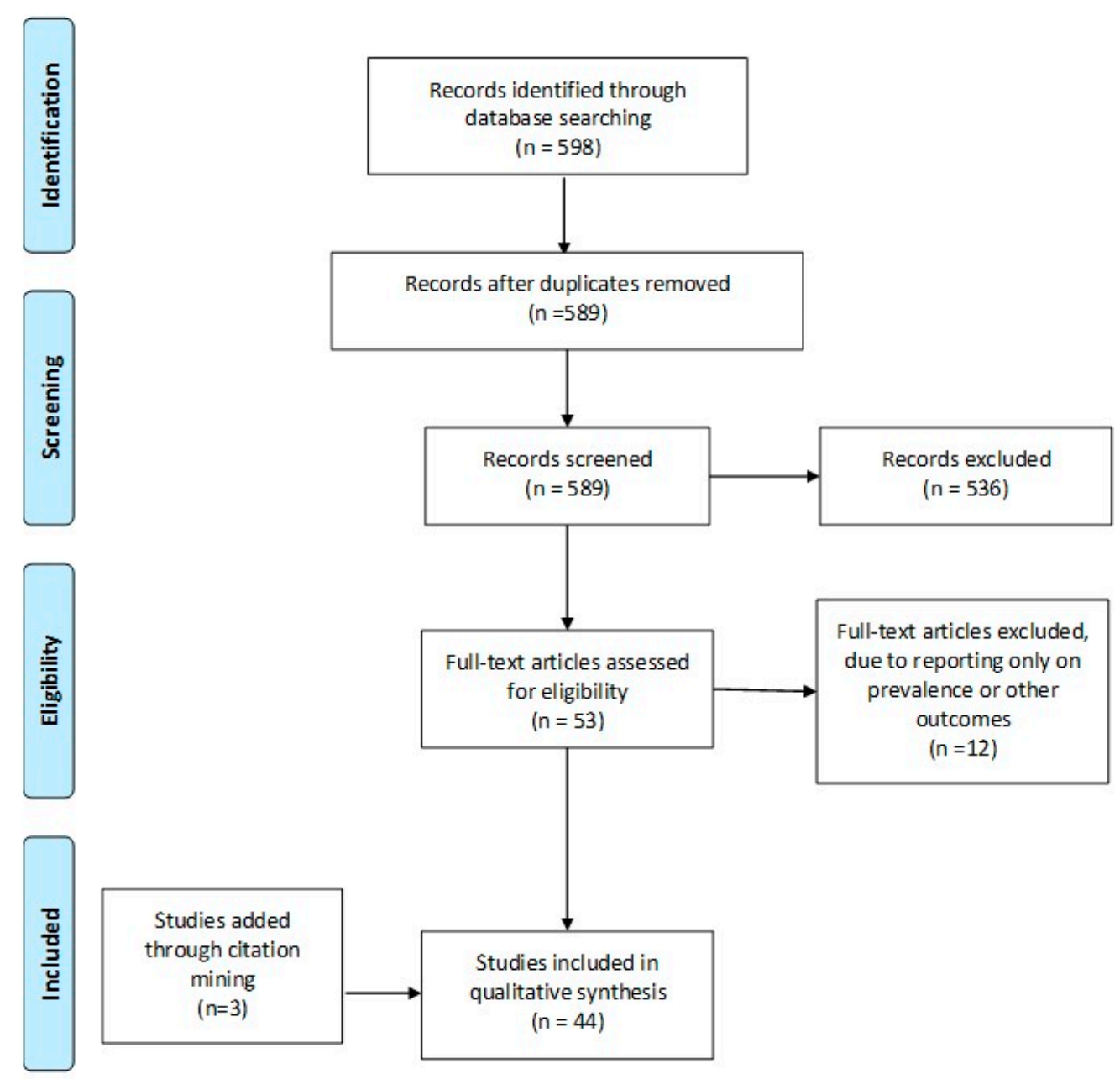

Figure 1. PRISMA flowchart.

\subsection{Study Selection}

Only studies that were performed following 2006 were included. As evidenced by the majority of literature, IVF from inception until 2006 reported continuous improvements regarding live birth rates [12]. Since 2006, live birth rates reached a plateau with adjustments reported each year. The population of the study included women undergoing IVF. The primary outcome measure was live birth rate and/or ongoing pregnancy (LB/OP). Both LB and OP were included, as many studies report on different findings and there is a lack of consensus on the desired outcome $[13,14]$. Secondary outcome measures were clinical pregnancy rate $(\mathrm{CP})$, biochemical pregnancy rate $(\mathrm{BP})$ and miscarriage rate. Miscarriage rate is calculated in regards to clinical pregnancy. 


\subsection{Data Extraction}

Even though data extraction is not commonly entailed in a systematic review, the authors decided to perform data extraction as the definition for each outcome was presented with great variety among the studies, ranging significantly from live-birth per cycle to live-birth per clinical pregnancy. The reporting of outcomes in a single-widely accepted-definition is of pivotal importance for the study to be comprehended. The authors herein define the biochemical, clinical pregnancy and live birth/ongoing pregnancy rates as the number of the aforementioned per woman per cycle. The miscarriage rate is defined as the number of patients' miscarriages per patients achieving a clinical pregnancy.

\section{Thyroid Related Autoantibodies}

It is well established in literature that thyroid dysfunction could jeopardize fecundity via several pathophysiological mechanisms. The hypothalamic-pituitary-thyroid (HPT) axis affects directly the function of the hypothalamic-pituitary-ovarian (HPO) axis, and vice versa. As a result, the two axes act together as an incorporated system. The physiological communication between HPT axis and HPO axis is mainly mediated mainly by a number of specific thyroid hormone receptors existing in the ovaries. Further to that, there is sufficient data demonstrating that estrogen directly affects the HPT axis functionality in the hypothalamus-pituitary level [15]. This incorporation is reflected in the fact that both hyperthyroid and hypothyroid women suffer from menstrual disturbances and anovulatory cycles, conditions that equally compromise fertility $[16,17]$.

The main cause leading to thyroid dysfunction is thyroid related auto-immunity. It is demonstrated that in women presenting with thyroid autoimmunity, namely Grave's disease and Hashimoto thyroiditis, the prevalence of infertility was very high and reached $47 \%$ and $52 \%$, respectively [18]. In a cross-sectional study nested within an ongoing prospective cohort study, the prevalence of thyroid auto-immunity in a cohort of infertile women was investigated. The results demonstrated that the prevalence of thyroid auto-immunity was statistically significant higher in the infertile group (19\%) in comparison to the control group consisting of fertile women (13\%). Furthermore, women with thyroid auto-immunity presented with a statistically significant higher serum thyroid stimulating hormone (TSH) and thyroid globulin auto-antibodies (Tg-Abs) levels in comparison to women without thyroid auto-immunity [19]. Other studies suggest that infertile women present with higher chances to be positive to anti-thyroperoxydase antibodies (anti-TPO) in comparison to age-matched fertile controls, even if they are euthyroid [20]. Additionally, several other published data provide indications regarding the possible relationship between thyroid auto-immunity and infertility [21]. Nonetheless, there is la ack of robust data to provide evidence for a causal relationship between thyroid auto-immunity and infertility and several dilemmas arise for the practitioners regarding the management of this special group of infertile patients during assisted reproduction treatment (ART) [22]. There are insufficient data regarding the direct impact of thyroid auto-antibodies (TAA) on IVF outcome, especially for TAA-positive euthyroid women.

Fourteen studies were considered suitable for inclusion in this systematic review as in all of them the possible effect of TAA in IVF outcome was investigated (Table 1) [9,11,23-34]. Data extraction was performed to provide information regarding the studies' general characteristics, the characteristics of the studies' groups and the IVF outcomes presented (Table 1). Eight out of 14 studies included in this review performed a retrospective data analysis $[9,24,27,28,30,31,33,34]$ and the other six were prospective cohort studies $[11,23,25,26,29,32]$. 
Table 1. Study characteristics regarding thyroid auto-antibodies.

\begin{tabular}{|c|c|c|c|c|c|c|c|c|c|c|}
\hline \multirow[t]{2}{*}{ Studies } & \multirow[t]{2}{*}{ Type of Study } & \multirow{2}{*}{$\begin{array}{c}\text { Type of } \\
\text { Auto-Antibodies }\end{array}$} & \multirow[t]{2}{*}{ Study Group } & \multirow[t]{2}{*}{ Control Group } & \multicolumn{2}{|c|}{ Clinical Pregnancy Rate } & \multicolumn{2}{|c|}{$\begin{array}{l}\text { Live Birth/Ongoing } \\
\text { Pregnancy Rate }\end{array}$} & \multicolumn{2}{|c|}{ Miscarriage Rate } \\
\hline & & & & & $\begin{array}{l}\text { Study } \\
\text { Group }\end{array}$ & $\begin{array}{l}\text { Control } \\
\text { Group }\end{array}$ & $\begin{array}{l}\text { Study } \\
\text { Group }\end{array}$ & $\begin{array}{l}\text { Control } \\
\text { Group }\end{array}$ & $\begin{array}{l}\text { Study } \\
\text { Group }\end{array}$ & $\begin{array}{l}\text { Control } \\
\text { Group }\end{array}$ \\
\hline Chen et al., $2017^{\text {a }}$ [11] & Prospective & TPO-Ab, TG-Ab & $\begin{array}{l}235 \text { TG-AB }(+), 214 \\
\text { TPO-Ab (+) }\end{array}$ & 844 TAA (-) women & $59.6 \%, 54.2 \%$ & $61 \%$ & $54.4 \%, 51.4 \%$ & $55.90 \%$ & $5.1 \%, 2.8 \%$ & $5.10 \%$ \\
\hline Caccavo et al., 2016 [23] & Prospective & $\begin{array}{l}\text { TPO-Ab, TG-Ab, } \\
\text { Anti-laminin } 1\end{array}$ & $\begin{array}{l}44 \text { Infertile Women } \\
\text { affected by HT }\end{array}$ & $\begin{array}{l}28 \text { Infertile Women } \\
\text { without HT }\end{array}$ & $9.1 \%$ & $31.1 \%$ & $\mathrm{n} / \mathrm{a}$ & $\mathrm{n} / \mathrm{a}$ & $\mathrm{n} / \mathrm{a}$ & $\mathrm{n} / \mathrm{a}$ \\
\hline Sakar et al., 2016 [32] & Prospective & TPO-Ab, TG-Ab & $\begin{array}{l}31 \text { (32 cycles) TAA (+) } \\
\text { women }\end{array}$ & $\begin{array}{c}121 \text { (126 cycles) TAA } \\
\text { (-) women }\end{array}$ & $21.90 \%$ & $20.60 \%$ & $15.60 \%$ & $15.10 \%$ & $6.30 \%$ & $5.50 \%$ \\
\hline Lukaszuk et al., 2015 [27] & Retrospective & TPO-Ab & 114 TAA (+) women & 495 TAA (-) women & $43.80 \%$ & $47.50 \%$ & $30.40 \%$ & $34.10 \%$ & $13.10 \%$ & $13.30 \%$ \\
\hline Tan et al., 2014 [33] & Retrospective & TPO-Ab, TG-Ab & 110 TAA (+) women & 725 TAA (-) women & $40.9 \%$ & $41.51 \%$ & $39.09 \%$ & $37.38 \%$ & $4.44 \%$ & $9.96 \%$ \\
\hline Mintzori et al., 2014 [34] & Retrospective & TPO-Ab, TG-Ab & $15 \mathrm{TAA}(+)$ women & 67 TAA (-) women & $33.33 \%$ & $37.31 \%$ & $26.67 \%$ & $34.32 \%$ & $20 \%$ & $8 \%$ \\
\hline Chai et al., 2014 [24] & Retrospective & TPO-Ab, TG-Ab & 89 TAA (+) women & 419 TAA (-) women & $44.90 \%$ & $45.80 \%$ & $32.60 \%$ & $36 \%$ & $9 \%$ & $8.80 \%$ \\
\hline Karacan et al., 2013 [25] & Prospective & TPO-Ab, TG-Ab & 34 TAA (+) women & 219 TAA (-) women & $35.30 \%$ & $40.60 \%$ & $32.40 \%$ & $37 \%$ & $2.90 \%$ & $3.60 \%$ \\
\hline Magri et al., 2013 [28] & Retrospective & TPO-Ab, TG-Ab & 60 TAA (+) women & 202 TAA (-) women & $28 \%$ & $35 \%$ & $\mathrm{n} / \mathrm{a}$ & $\mathrm{n} / \mathrm{a}$ & $\mathrm{n} / \mathrm{a}$ & $\mathrm{n} / \mathrm{a}$ \\
\hline Zhong et al., 2012 [9] & Retrospective & TPO-Ab, TG-Ab & 90 TAA (+) women & 676 TAA (-) women & $33.3 \%$ & $46.7 \%$ & $24.33 \%$ & $41.20 \%$ & $8.97 \%$ & $5.50 \%$ \\
\hline Monteleone et al., 2011 [29] & Prospective & TPO-Ab, TG-Ab & 14 TAA (+) women & 17 TAA $(-)$ women & $\mathrm{n} / \mathrm{a}$ & $\mathrm{n} / \mathrm{a}$ & $\mathrm{n} / \mathrm{a}$ & $\mathrm{n} / \mathrm{a}$ & $40 \%$ & $17 \%$ \\
\hline Revelli et al., 2009 [31] & Retrospective & TPO-Ab, TG-Ab & 52 TAA (+) women & 200 TAA (-) women & $7.6 \%$ & $33 \%$ & $6 \%$ & $29 \%$ & $25 \%$ & $12 \%$ \\
\hline Kilic et al., 2008 [26] & $\begin{array}{l}\text { Cross-sectional } \\
\text { and Prospective }\end{array}$ & TPO-Ab, TG-Ab & $23 \mathrm{TAA}(+)$ women & 31 TAA (-) women & $30.40 \%$ & $41.90 \%$ & $\mathrm{n} / \mathrm{a}$ & $\mathrm{n} / \mathrm{a}$ & $\mathrm{n} / \mathrm{a}$ & $\mathrm{n} / \mathrm{a}$ \\
\hline Negro et al., 2007 [30] & Retrospective & TPO-Ab & 42 TAA (+) women & 374 TAA (-) women & $50 \%$ & $62.60 \%$ & $28.57 \%$ & $55.34 \%$ & $11.90 \%$ & $7.20 \%$ \\
\hline
\end{tabular}

${ }^{\mathrm{a}}$ : Chen et al., 2017, presents patients positive for more than one auto-antibody, thus cumulative results cannot be provided. 
Three studies report on BP rate [26,29,32]. No statistically significant difference was observed. Fourteen studies reported on CP rates [9,11,23-34]. Eight of the aforementioned studies were of retrospective nature and the remaining five of prospective. Only three studies observed a statistically significant lower $\mathrm{CP}$ rate in the TAA positive group $[9,23,26]$. These findings are in accordance with three previous meta-analyses performed in the field [35-37].

Eleven studies reported on miscarriage rate $[9,11,24,25,27,29-34]$. Only one study reported a higher miscarriage rate in the TAA positive group, while the remaining ten demonstrated no statistically significant difference. The increase in miscarriage rate is also demonstrated in two of the three meta-analyses $[35,37]$. This is attributed to the sample size as evident in Busnelli's meta-analysis. Ten studies reported results on LB/OP rate $[9,11,24,25,27,30-34]$. Seven of the included studies were of retrospective nature and the remaining three of prospective. The sample size ranged from 82-1239 cycles. No study reported a statistically significant difference in LB/OP rates. Only one out of three meta-analyses reported lower LB/OP rates. It may be possible that a well-designed prospective cohort study will delineate the possible impact of TAA on LB/OP in IVF cycles. The sourced data for each of the above outcomes is graphically presented in Figure 2.

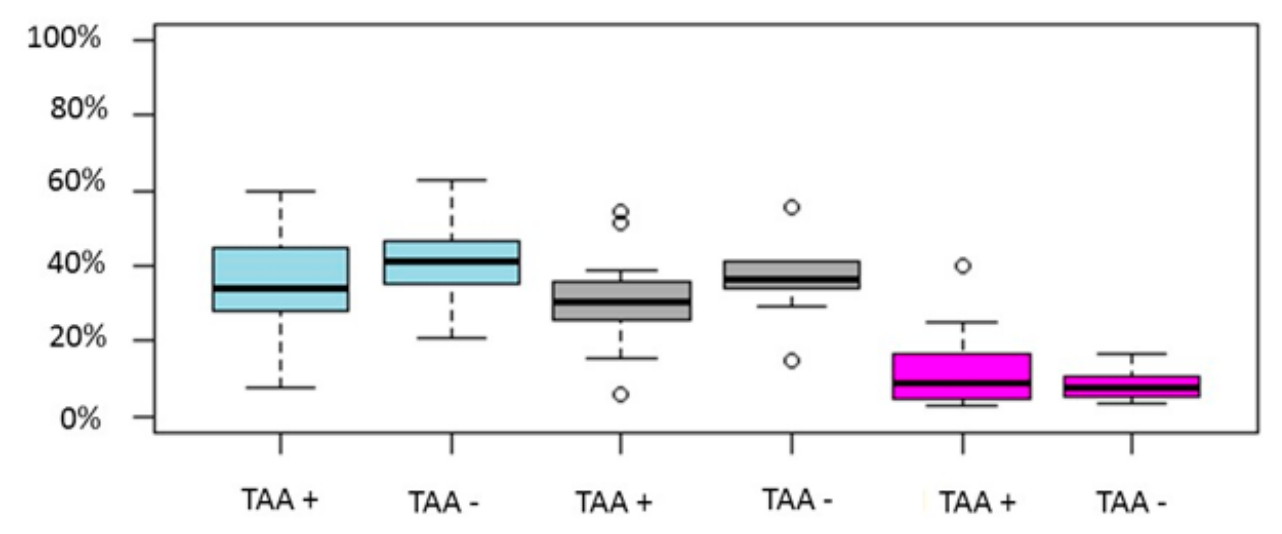

Figure 2. Boxplot regarding CP, LB/OP and miscarriage rates between TAA positive and TAA negative women. Blue color represent $\mathrm{CP}$ rate, grey $\mathrm{LB} / \mathrm{OP}$ rate and magenta represent miscarriage rates. Circles in the figure represent outliers -values outside the $1.5 x$ interquartile range.

In conclusion, following evaluation of the evidence published from 2006 to 2018, TAA presence in euthyroid women appears not be correlated with poorer outcomes following IVF/ICSI cycles. Regarding the miscarriage rates, the conclusions are conflicting and the consensus debatable, as there is data demonstrating that the miscarriage rate is not correlated with TAA presence, while other studies support the opposite, as buttressed by a meta-analysis published by Toulis et al. (2010) [35]. Nonetheless, the maternal TAA positivity could impair IVF/ICSI outcomes when overt thyroid dysfunction or subclinical hypothyroidism are co-existent. It should be highlighted, that studies included in this systematic review have enrolled populations of varying characteristics and diverse infertility etiologies. Thus, the level of heterogeneity among them is assessed as being considerably high. Further to that, the included studies herein, employed dissimilar cut-off levels and understandably entail different laboratory methods in order to evaluate the thyroid hormonal profile, this may serve as a consideration. Regarding infertility treatment, numerous IVF/ICSI treatment protocols have also been employed among the different studies. The main limitation observed in the great majority of the studies and especially in consideration to the prospective studies, is the small sample size of the studied populations. As a result, the strength of the provided evidence within the published literature is restricted. Robust data provided by future larger prospective studies and meta-analyses would provide more robust evidence in order to address the possible effects of the TAA in IVF/ICSI outcome. This will contribute considerably, towards a consensus and subsequent implementation of a common universal protocol on the optimal management of the euthyroid TAA 
positive women in assisted reproductive medicine. Data provided in this study are in the same line with these provided by others studies in the field $[10,36]$ and concordant with the current Guidelines of the American Thyroid Association for the Diagnosis and Management of Thyroid Disease During Pregnancy and the Postpartum published in 2017 [22].

\section{Anti-Phospholipid Antibodies}

The Anti-Phospholipid Syndrome (APS), diagnosed by the presence of anti-phospholipid antibodies (aPL) has been associated with various pregnancy-related complications, such as pre-eclampsia, still birth, pre-term delivery and miscarriages [38-40]. Numerous studies have linked aPL to infertility, though safe conclusions cannot be reached yet [10]. In 2017 EULAR guidelines have been published regarding the management of patients with APS and/or Lupus [41]. According to guidelines ART is a safe procedure for the patient, although precautious treatment entailing low-dose aspirin, heparin, and antithrombotic treatment is suggested. The employment of natural cycles to avoid ovarian hyperstimulation syndrome is mentioned but due to the lower success rates no recommendation has been published. The stimulation protocols that should be employed are the ones suggested by Bellver and Pellicer [42].

Fifteen studies were identified including anti-Phospholipid antibodies and IVF outcome [11,43-56]. Most of the included studies were of prospective nature, while three of retrospective, one1 case report, and two case series were included. Data extraction was performed with respect to provide information regarding to the studies' general characteristics, the characteristics of the studies' groups and the IVF outcomes presented (Table 2). 
Table 2. Study characteristics regarding anti-phospholipid autoantibodies.

\begin{tabular}{|c|c|c|c|c|c|c|c|c|c|c|}
\hline \multirow{2}{*}{ Studies } & \multirow{2}{*}{ Type of Study } & \multirow{2}{*}{ Type of Auto-Antibodies } & \multirow{2}{*}{ Study Group } & \multirow{2}{*}{$\begin{array}{l}\text { Control } \\
\text { Group }\end{array}$} & \multicolumn{2}{|c|}{ Clinical Pregnancy Rate } & \multicolumn{2}{|c|}{$\begin{array}{c}\text { Live Birth/Ongoing } \\
\text { Pregnancy Rate }\end{array}$} & \multicolumn{2}{|c|}{ Miscarriage Rate } \\
\hline & & & & & $\begin{array}{l}\text { Study } \\
\text { Group }\end{array}$ & $\begin{array}{l}\text { Control } \\
\text { Group }\end{array}$ & $\begin{array}{l}\text { Study } \\
\text { Group }\end{array}$ & $\begin{array}{l}\text { Control } \\
\text { Group }\end{array}$ & $\begin{array}{l}\text { Study } \\
\text { Group }\end{array}$ & $\begin{array}{l}\text { Control } \\
\text { Group }\end{array}$ \\
\hline Di Nisio et al., 2018 [43] & Prospective & $\begin{array}{c}\text { Lupus anticoagulant, } \\
\text { Anti-cardiolipin antibodies, Anti- } \\
\beta 2 \text {-glycoprotein antibodies }\end{array}$ & $57 \mathrm{aPL}(+)$ women & $\begin{array}{l}598 \text { aPL }(-) \\
\text { women }\end{array}$ & $31.58 \%$ & $29.26 \%$ & $12.28 \%$ & $20.23 \%$ & $61.11 \%$ & $30.86 \%$ \\
\hline Hong et al., 2018 [44] & Prospective & $\begin{array}{c}\text { Lupus anticoagulant, } \\
\text { Anti-cardiolipin antibodies, } \\
\text { anti- } \beta 2 \text {-glycoprotein } 1 \text { antibody }\end{array}$ & $12 \mathrm{aPL}(+)$ women & $\begin{array}{l}181 \text { aPL }(-) \\
\text { women }\end{array}$ & $66.67 \%$ & $45.86 \%$ & $58.33 \%$ & $37.02 \%$ & $12.50 \%$ & $19.28 \%$ \\
\hline Andreeva et al., 2017 [45] & Case Report & IgA-anti- $\beta 2 \mathrm{GPI}$ & $\mathrm{n} / \mathrm{a}$ & $\mathrm{n} / \mathrm{a}$ & $\mathrm{n} / \mathrm{a}$ & $\mathrm{n} / \mathrm{a}$ & $\mathrm{n} / \mathrm{a}$ & $\mathrm{n} / \mathrm{a}$ & $\mathrm{n} / \mathrm{a}$ & $\mathrm{n} / \mathrm{a}$ \\
\hline Chen et al., 2017 a [11] & Prospective & $\begin{array}{c}\text { aCL-IgG, aCL-IgM, a } \beta 2 \text { GPI-IgG, } \\
\text { a } \beta 2 \text { GPI-IgM }\end{array}$ & $\begin{array}{l}193 \text { aCL-IgG (+) women, } 202 \\
\text { aCL-IgM (+) women, } 22 \\
\text { aß2GI-IgG (+) women, } 246 \\
\text { aß2GPI-IgM (+) women }\end{array}$ & $\begin{array}{l}844 \mathrm{aPL}(-) \\
\text { women }\end{array}$ & $\begin{array}{l}58.0 \% \\
63.4 \% \\
36.4 \% \\
55.7 \% \\
\end{array}$ & $61.02 \%$ & $\begin{array}{l}48.18 \% \\
53.96 \% \\
31.81 \% \\
50.81 \% \\
\end{array}$ & $55.92 \%$ & $\begin{array}{c}17.00 \% \\
14.8 \% \\
12.50 \% \\
8.80 \% \\
\end{array}$ & $8.35 \%$ \\
\hline Orquevaux et al., 2017 b $[46]$ & Retrospective & $\begin{array}{c}\text { Lupus anticoagulant, } \\
\text { Anti-cardiolipin antibodies, } \\
\text { anti- } \beta 2 \text {-glycoprotein } 1 \text { antibody }\end{array}$ & $\begin{array}{c}12 \mathrm{SLE}+\mathrm{aPL}(+) / \text { APS women } \\
10 \mathrm{APS} \text { women }\end{array}$ & $\begin{array}{l}15 \text { SLE }+ \text { aPL } \\
(-) \text { women }\end{array}$ & $25 \%$ & $32.43 \%$ & $\mathrm{n} / \mathrm{a}$ & $\mathrm{n} / \mathrm{a}$ & $\mathrm{n} / \mathrm{a}$ & $\mathrm{n} / \mathrm{a}$ \\
\hline Paulmyer-Lacroix et al., 2014 [47] & Retrospective & $\begin{array}{l}\text { Lupus anticoagulant, } \\
\text { Anti-cardiolipin antibodies, } \\
\text { IgA-anti- } \beta 2 \text { GPI }\end{array}$ & $8 \mathrm{aPL}(+)$ women & $\begin{array}{l}32 \text { aPL }(-) \\
\text { women }\end{array}$ & $50.00 \%$ & $53.13 \%$ & $0.00 \%$ & $18.75 \%$ & $100.00 \%$ & $64.71 \%$ \\
\hline Da Costa et al., 2012 [48] & Retrospective & $\begin{array}{l}\text { Lupus anticoagulant, } \\
\text { Anti-cardiolipin antibodies }\end{array}$ & $34 \mathrm{aPL}(+)$ women & $\begin{array}{c}205 \text { aPL (-) } \\
\text { women }\end{array}$ & $\mathrm{n} / \mathrm{a}$ & $\mathrm{n} / \mathrm{a}$ & $\mathrm{n} / \mathrm{a}$ & $\mathrm{n} / \mathrm{a}$ & $\mathrm{n} / \mathrm{a}$ & $\mathrm{n} / \mathrm{a}$ \\
\hline Ragab et al.,2012 [49] & Case Series & $\begin{array}{l}\text { Lupus anticoagulant, } \\
\text { Anti-cardiolipin antibodies }\end{array}$ & $\mathrm{n} / \mathrm{a}$ & $\mathrm{n} / \mathrm{a}$ & $\mathrm{n} / \mathrm{a}$ & $\mathrm{n} / \mathrm{a}$ & $\mathrm{n} / \mathrm{a}$ & $\mathrm{n} / \mathrm{a}$ & $\mathrm{n} / \mathrm{a}$ & $\mathrm{n} / \mathrm{a}$ \\
\hline Ulcova-Gallova, 2012 [50] & Case Series & Anti-cardiolipin antibodies & $\mathrm{n} / \mathrm{a}$ & $\mathrm{n} / \mathrm{a}$ & $\mathrm{n} / \mathrm{a}$ & $\mathrm{n} / \mathrm{a}$ & $\mathrm{n} / \mathrm{a}$ & $\mathrm{n} / \mathrm{a}$ & $\mathrm{n} / \mathrm{a}$ & $\mathrm{n} / \mathrm{a}$ \\
\hline Ying et al., 2012 [51] & Retrospective & Anti-cardiolipin antibodies & $60 \mathrm{ACA}(+)$ women & $\begin{array}{l}518 \text { ACA (-) } \\
\text { women }\end{array}$ & $26.67 \%$ & $44.98 \%$ & $\mathrm{n} / \mathrm{a}$ & $\mathrm{n} / \mathrm{a}$ & $31.25 \%$ & $15.88 \%$ \\
\hline Zhong et al., 2011 [52] & Retrospective & Anti-cardiolipin antibodies & $80 \mathrm{ACA}(+)$ women & $\begin{array}{l}788 \text { ACA (-) } \\
\text { women }\end{array}$ & $31.25 \%$ & $48.60 \%$ & $\mathrm{n} / \mathrm{a}$ & $\mathrm{n} / \mathrm{a}$ & $32.00 \%$ & $19.32 \%$ \\
\hline Lee et al., 2007 [53] & Prospective & $\begin{array}{l}\text { Anti-cardiolipin antibody, lupus } \\
\text { anticoagulant }\end{array}$ & $39 \mathrm{aPL}(+)$ women & $\begin{array}{l}142 \text { aPL }(-) \\
\text { women }\end{array}$ & $20.51 \%$ & $17.61 \%$ & $7.69 \%$ & $14.08 \%$ & $62.50 \%$ & $20.00 \%$ \\
\hline Sanmarco et al., 2007 [54] & Prospective & $\begin{array}{c}\text { Lupus anticoagulant, } \\
\text { Anti-cardiolipin antibodies, } \\
\text { anti- } \beta 2 \text {-glycoprotein } 1 \text { antibody }\end{array}$ & $40 \mathrm{aPL}(+)$ women & $\begin{array}{l}61 \mathrm{aPL}(-) \\
\text { women }\end{array}$ & $27.50 \%$ & $19.67 \%$ & $22.50 \%$ & $13.11 \%$ & $18.18 \%$ & $33.33 \%$ \\
\hline Buckingham et al., 2006 [55] & Prospective & $\begin{array}{l}\text { Anti-cardiolipin antibodies, } \\
\text { anti- } \beta 2 \text {-glycoprotein } 1 \text { antibody, } \\
\text { phosphatidylserine }\end{array}$ & $19 \mathrm{aPL}(+)$ women & $\begin{array}{l}80 \mathrm{aPL}(-) \\
\text { women }\end{array}$ & $31.58 \%$ & $36.25 \%$ & $15.79 \%$ & $23.75 \%$ & $\mathrm{n} / \mathrm{a}$ & $\mathrm{n} / \mathrm{a}$ \\
\hline Matsubayashi et al., $2006^{b}[56]$ & Prospective & $\begin{array}{l}\text { Anti-cardiolipin antibodies, } \\
\text { anti- } \beta 2 \text {-glycoprotein } 1 \text { antibody, }\end{array}$ & $17 \mathrm{aPL}(+)$ women & $\begin{array}{l}27 \text { aPL }(-) \\
\text { women }\end{array}$ & $29.41 \%$ & $33.33 \%$ & $\mathrm{n} / \mathrm{a}$ & $\mathrm{n} / \mathrm{a}$ & $\mathrm{n} / \mathrm{a}$ & $\mathrm{n} / \mathrm{a}$ \\
\hline
\end{tabular}

a: Chen et al., 2017, presents patients positive for more than one auto-antiboy, thus cumulative results cannot be provided; ${ }^{\mathrm{b}}$ : The data regarding the Matsubayashi et al., 2006 study were obtained from a letter to the editor by Matsubayashi and colleagues ([57]) for Buckingham et al., 2006 study. 
Out of 12 cohort studies, 11 employed aPL-negative women as controls [11,43,44,47,48,51-56] and one employed women with Lupus as control group [46]. Regarding cohort studies employing aPL-negative women as controls, seven studies reported on LB/OP rate [11,43,44,47,53-55], ten studies reported on clinical pregnancy rate $[11,43,44,47,51-56]$ and eight studies on miscarriage rate $[11,43,44$, 47,51-54]. One study reported only on biochemical pregnancy (positive pregnancy test) [48].

Regarding the case report by Andreeva and colleagues [45], the authors presented the case of an infertile female patient negative for APS by standard diagnostic protocol, but diagnosed with Systemic Lupus Erythematosus (SLE). Following further evaluation, the patient was positive for IgA Anti- 32 glycoprotein I Antibodies, suggesting APS. The patient achieved a pregnancy following the first IVF cycle, indicating that an IVF cycle may present an approach for APS and SLE patients. The case-series by Ulcova-Gallova [50] suggests the employment of PGD for patients with APS and repeated pregnancy loses. Finally, the case series by Ragab and colleagues suggested the employment of ART for infertile patients with APS. Out of five patients enrolled in the study one achieved a pregnancy thus opening a new line of approach for these patients [49].

The study by Orquevaux and colleagues [46] investigated the safety of IVF when performed on patients with SLE and/or APS. Thirty-seven patients underwent a total of 97 cycles. Twenty-six out of 37 achieved a healthy delivery, whereas only 8 cycles resulted in complications. Similarly, Da Costa's study evaluated the effects of two aPLs, namely anticardiolipin antibody and lupus anticoagulant in women undergoing IVF. Comparable biochemical pregnancy rates were observed regarding aPL-positive $(n=30)$ and aPL-negative women $(n=181)$. The study did not report on clinical, ongoing pregnancy, or live birth rates.

Regarding the 10 studies that presented with aPL-negative women serving as the control group, the study size ranged from 40-1239 cycles. The sample size of cycles with aPL-positive women ranged from 8 to 395, whereas the control group size ranged from 27-844 cycles. No study presented with statistically significant different LB/OP rate. Only two studies presented with a statistically significant lower clinical pregnancy rate for aPL-positive women [51,52]. Both studies were of retrospective nature. The pooled results of the studies are graphically presented in Figure 3.

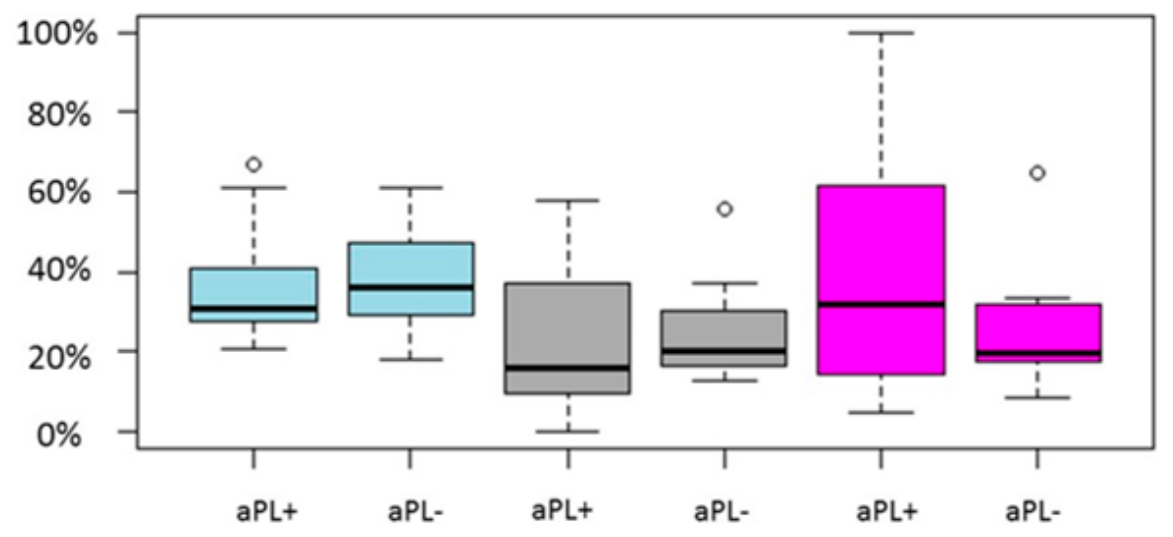

Figure 3. Boxplot regarding $\mathrm{CP}, \mathrm{LB} / \mathrm{OP}$ and miscarriage rates between aPL positive and aPL negative women. Blue color represent $\mathrm{CP}$ rate, grey $\mathrm{LB} / \mathrm{OP}$ rate and magenta represent miscarriage rate. Circles in the figure represent outliers -values outside the $1.5 x$ interquartile range.

In conclusion, as reported by the studies analyzed herein, the presence of aPL does not appear to influence neither ongoing pregnancy/live birth rates nor clinical pregnancy rates. The consideration that pooled results may alter the outcome should not be overlooked. The option of a meta-analysis including the current studies was rejected as it would lead to low quality evidence, thus constituting it more confusing than delineating. As anticipated, a higher miscarriage rate was observed in the majority of the reports. The fact that the presence of aPL did not decrease pregnancy rates is of pivotal importance as it indicates both the safety and the efficacy of IVF for infertile women diagnosed as 
aPL-positive. Nonetheless, it should be highlighted that IVF cycles that corresponded to women positive for aPL represented solely one quarter in comparison to the control. This fact could be attributed to the estimated prevalence of aPL in the population of women diagnosed with unexplained or immunological-based infertility.

\section{Antinuclear Antibodies-ANAs}

Antinuclear antibodies (ANAs) are auto-antibodies related to systematic autoimmune disorders. They constitute a large group of auto-antibodies targeting several cellular antigens such as double-strand DNA (ds-DNA), RNA molecules, mitochondria antigens, several proteins in the cytoplasm and in the nucleus, and their complexes. Among the types of ANAs are the anti-ds DNA antibodies, anti-centromere antibodies (ACA) and the anti-extractable nuclear antigens antibodies (anti-ENAs) [58,59]. It is well documented that ANAs are implicated to the pathogenesis of several systematic autoimmune disorders [60-67]. Evidence provided from the literature indicates that the presence of ANAs is also associated with immunologically induced infertility. However, the underlying mechanisms leading to this association are to date under investigation. There is data indicating that women with high levels of ANA in their sera have also elevated ANA levels in their follicular fluids and these levels are documented to be negatively correlated with the number of good quality embryos obtained in IVF/ICSI cycles [68]. Further to that, in vivo experiments employed in mouse models demonstrate that the presence of ANAs in the oocytes and in the embryos' culture media could compromise oocyte maturation and embryo development, respectively [68,69]. These observations, lead the researchers to conclude that ANAs could directly compromise oocyte maturation and embryo development leading finally to infertility [70-72].

In several studies the prevalence of ANA is recorded to be higher in women presenting with fertility disorders than in fertile women. Interestingly, as indicated from a large cohort study, the presence of ANA is negatively correlated with parity [73-75]. Nonetheless, there are still insufficient data regarding the direct impact of ANAs on IVF/ICSI outcome, especially for ANA positive women presenting with an undisturbed immunologic profile.

Seven studies were considered suitable for inclusion in this systematic review as in all of them the possible effect of ANAs in IVF/ICSI outcome was investigated [11,68,76-80]. Data extraction was performed to provide information regarding the studies' general characteristics, such as year of publication, type of the study, type of ANAs investigated, along with the characteristics of the studies' groups and the IVF/ICSI outcomes presented, referring to biochemical pregnancy rates, clinical pregnancy rate, live birth rate, miscarriage rate (Table 3). Four out of seven studies included in this review performed a retrospective data analysis and the other three were prospective cohort studies. However, it should be mentioned that the authors in four out of the seven studies [68,76-78] did not provide exact information regarding the nature of the studies-whether prospective or retrospective- and thus conclusions were drawn from information provided in regards to the patients' consent statements. 
Table 3. Study characteristics regarding Anti-nuclear auto-antibodies.

\begin{tabular}{|c|c|c|c|c|c|c|c|c|c|c|}
\hline \multirow{2}{*}{ Studies } & \multirow{2}{*}{ Type of Study } & \multirow{2}{*}{$\begin{array}{c}\text { Type of } \\
\text { Auto-Antibodies }\end{array}$} & \multirow{2}{*}{ Study Group } & \multirow{2}{*}{ Control Group } & \multicolumn{2}{|c|}{ Clinical Pregnancy Rate } & \multicolumn{2}{|c|}{$\begin{array}{l}\text { Live Birth/Ongoing } \\
\text { Pregnancy Rate }\end{array}$} & \multicolumn{2}{|c|}{ Miscarriage Rate } \\
\hline & & & & & $\begin{array}{l}\text { Study } \\
\text { Group }\end{array}$ & $\begin{array}{l}\text { Control } \\
\text { Group }\end{array}$ & $\begin{array}{l}\text { Study } \\
\text { Group }\end{array}$ & $\begin{array}{l}\text { Control } \\
\text { Group }\end{array}$ & $\begin{array}{l}\text { Study } \\
\text { Group }\end{array}$ & $\begin{array}{l}\text { Control } \\
\text { Group }\end{array}$ \\
\hline Chen et al., 2017 [11] & Prospective & -ANA & -178 ANA(+) Women & -844 ANA(-) Women & $55.60 \%$ & $61 \%$ & $50.56 \%$ & $55.90 \%$ & $9.10 \%$ & $8.30 \%$ \\
\hline Fan et al., 2017 [76] & Not provided & $\begin{array}{c}\text {-ANA } \\
\text {-Anti-dsDNA } \\
\end{array}$ & $\begin{array}{l}-52 \mathrm{ANA}(+) \text { and Anti-dsDNA(+) Women } \\
-86 \mathrm{ANA}(+) \text { and Anti-dsDNA }(-) \text { Women } \\
\end{array}$ & $\begin{array}{c}-121 \text { ANA }(-) \text { and } \\
\text { Anti-dsDNA(-) Women }\end{array}$ & $\begin{array}{l}11.5 \% \\
30.2 \% \\
\end{array}$ & $47.10 \%$ & $\begin{array}{c}0 \% \\
18.6 \% \\
\end{array}$ & $36.30 \%$ & $\begin{array}{l}100 \% \\
38.5 \% \\
\end{array}$ & $22.80 \%$ \\
\hline Li et al., 2015 [77] & Not provided & -ANA & -204 ANA(+) Women & -313 ANA(+) Women & $27.72 \%$ & $45.03 \%$ & $21.78 \%$ & $43.50 \%$ & $21.43 \%$ & $3.39 \%$ \\
\hline Ying et al., 2013 [79] & Retrospective & $\begin{array}{l}-\mathrm{ANA} \\
-\mathrm{ACA}\end{array}$ & $\begin{array}{l}-20 \mathrm{ANA}(+) \text { and } \mathrm{ACA}(+) \text { Women } \\
-51 \mathrm{ANA}(+) \text { and } \mathrm{ACA}(-) \text { Women }\end{array}$ & $\begin{array}{l}-116 \mathrm{ANA}(-) \text { and } \mathrm{ACA}(-) \\
\text { Women }\end{array}$ & $\begin{array}{r}25 \% \\
35.3 \% \\
\end{array}$ & 53.40 & $\mathrm{n} / \mathrm{a}$ & $\mathrm{n} / \mathrm{a}$ & $\mathrm{n} / \mathrm{a}$ & $\mathrm{n} / \mathrm{a}$ \\
\hline Zhu et al., 2013 [80] & Retrospective & -ANA & -66 ANA $(+)$ Women & -233 ANA(-) Women & $17.30 \%$ & $56.50 \%$ & $9.61 \%$ & $51.10 \%$ & $44.40 \%$ & $9.62 \%$ \\
\hline Ying et al., 2013 [78] & Not provided & -ANA & -50 ANA $(+)$ Women & -50 ANA (-) Women & $28 \%$ & $52 \%$ & $\mathrm{n} / \mathrm{a}$ & $\mathrm{n} / \mathrm{a}$ & $\mathrm{n} / \mathrm{a}$ & $\mathrm{n} / \mathrm{a}$ \\
\hline Ying et al., 2012 [68] & Not provided & -ANA & -66 ANA(+) Women & -233 ANA(-) Women & $28.10 \%$ & $46.40 \%$ & $\mathrm{n} / \mathrm{a}$ & $\mathrm{n} / \mathrm{a}$ & $\mathrm{n} / \mathrm{a}^{\mathrm{a}}$ & $\mathrm{n} / \mathrm{a}^{\mathrm{a}}$ \\
\hline
\end{tabular}

a: In Ying et al., 2012 study miscarriage rates was provided per gestational sacks, thus, information on miscarriages per clinical pregnancy could not be extracted. 
Five out of seven studies included in this systematic review investigated the impact of ANAs in the IVF/ICSI outcome, considered ANAs as a single category of autoantibodies. Two out of five studies were of retrospective nature $[68,80]$, while the remaining three were prospective $[11,77,78]$. In all of these studies, the study group consisted of sero-positive for ANA (ANA+) infertile women while sero-negative for ANA (ANA-) women were serving as a control. All women participated were infertile women presenting with different types of infertility etiologies. Etiologies ranged greatly from women suffering from autoimmune disorders to women who had a history of a known medical treatment or surgeries that could compromise fertility were excluded. The studies' size ranged from 100-1022 cycles. The sample size of cycles with ANA positive women ranged from 50 to 202, whereas the control group size ranged from 50-844 cycles. Regarding the IVF/ICSI outcomes investigated in this systematic review, three studies reported on live birth rate/ongoing pregnancy rates, five studies reported on clinical pregnancy rates, and four studies on miscarriage rate. Only two studies reported on positive hCG test rates.

Regarding live birth/ongoing pregnancy rates a noteworthy difference was observed between ANA positive group and ANA negative group in two out of three studies [77,80], while, in the study of Chen et al. (2017) [11] no statistically significant difference could be established between the two groups. ANA positive women presented with statistically significant decreased clinical pregnancy rate in four out five studies $[68,77,78,80]$. Similar to live birth/ongoing pregnancy rates, in the study of Chen et al. (2017) [11] clinical pregnancy rate did not differ significantly between the two groups. In both studies presenting data regarding biochemical pregnancy rate, the ANA positive group presented with a statistically significant decreased positive hCG test rate compared to ANA negative group [77,78]. In regards to miscarriage rates, the results are controversial. According to Li et al. (2015) and Zhu et al. $(2013)[77,80]$ ANA positivity was correlated with higher miscarriage rates, while in the studies of Chen et al. (2017) and Ying et al. (2012) such a correlation could not be established [11,68]. Data regarding the live birth rate/ongoing pregnancy rate, the clinical pregnancy rate, the positive hCG test rate and the miscarriage rate is provided in Table 3. Pooled results of the above outcomes are graphically represented in Figure 4.

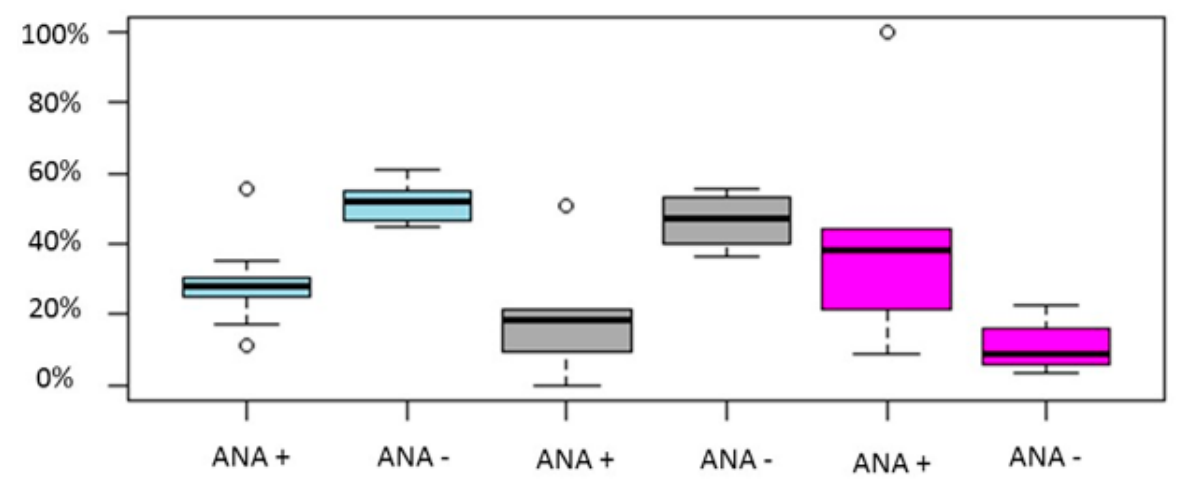

Figure 4. Boxplot regarding $\mathrm{CP}, \mathrm{LB} / \mathrm{OP}$ and miscarriage rates between ANA positive and ANA negative women. Blue color represents $\mathrm{CP}$ rate, grey $\mathrm{LB} / \mathrm{OP}$ rate and magenta represents miscarriage rates. Circles in the figure represent outliers -values outside the $1.5 \mathrm{x}$ interquartile range.

Further to that, some studies indicate that ANAs presence could impair the fertilization rate and the number of good quality embryos and thus could lead to IVF/ICSI failure $[68,78,80]$. In addition, there are indications that the presence of specific ANAs subclasses, namely Anti-Rib-p, anti-Jo-1, and anti-dsDNA antibodies, correlate with a high risk of implantation failure and early miscarriages in women undergoing IVF/ICSI treatment [77]. The same study documented an observation of high significance, namely that not only infertile women but similarly fertile women could be ANA positive. Nevertheless, only infertile women presented with a high ANA titer ( $>1: 320)$ [77]. In the study of Zhu et al. (2013), the effectiveness of the prednisolone plus low-dose aspirin adjuvant treatment 
for ANA positive women on IVF/ICSI outcome was investigated. Study results indicate that ANA positive women who were treated with adjuvant treatment employing prednisolone plus low-dose aspirin, exhibited a significantly better overall IVF performance in comparison to the untreated patients. Authors highlighted that the prednisolone plus low-dose aspirin administration could be beneficial for ANA positive women undergoing IVF treatment. Due to the retrospective nature and the small size of participants included in some of the groups, this study involved a high risk of bias. Consequently, the study's outcomes should be verified by large, randomized-controlled trials prior to application in clinical practice [80].

The remaining two out of the seven studies included in this systematic review investigated the impact of specific ANAs subcategories in the IVF/ICSI outcome [76,79]. Data regarding the type of ANAs investigated, the live birth rate/ongoing pregnancy rate, the clinical pregnancy rate, the positive hCG test rate and the miscarriage rate are provided in Table 3.

In the first study, Fan et al. (2017) [76] retrospectively investigated the impact of anti-dsDNA autoantibodies on IVF outcome. Fifty-two women with positive ANA and anti-ds DNA antibodies (ANA positive/anti-ds DNA positive group) were compared to 86 women with positive ANA and negative anti-ds DNA antibodies (ANA positive/anti-ds DNA negative group) and 121 women with negative ANA and anti-ds DNA antibodies (ANA negative/anti-ds DNA negative group). Patients positive for other autoantibodies, such as thyroid autoantibodies or anticardiolipin antibodies, or patients with autoimmune diseases or clinical presentations of autoimmune diseases were excluded from the study. ANA positive/anti-ds DNA positive group was presented with statistically significant decreased clinical pregnancy rate and statistically significant increased miscarriage rate compared with both ANA positive/anti-ds DNA negative group and ANA negative/anti-ds DNA negative group. In addition, data extraction revealed that the live birth rate/ongoing pregnancy rate was also noteworthy decreased in the ANA positive/anti-ds DNA positive group compared with both ANA positive/anti-ds DNA negative group and ANA negative/anti-ds DNA negative group, as no live birth/ongoing pregnancy could be achieved in ANA positive/anti-ds DNA positive. Authors concluded that ANA presence may be an essential marker for oocyte quality and embryo development in infertile women positive for any type of ANA. It should be highlighted that authors do not provide clear evidence regarding the distribution of infertility etiologies among the study's groups, a parameter which possess the major limitation of this study.

In the second study published from the same team as the first one, Ying et al. (2013) [79] retrospectively investigated the impact of ACA on oocyte maturation and embryo development in ICSI cycles. Twenty women with positive ANA and ACA (ANA positive/ACA positive group) were compared to 51 women with positive ANA and negative ACA (ANA positive/ACA negative group) and 116 women with negative ANA and ACA (ANA negative/ACA negative group). Women who presented with a history of a known medical treatment or surgeries that could compromise fertility were excluded from the study. ANA positive/ACA positive group presented with a statistically significant decreased number of high-quality embryos, biochemical and clinical pregnancy rates compared with ANA negative/ACA negative group. Authors concluded that ACA presence may be an essential marker for oocyte quality and embryo development in infertile women positive for any type of ANA undergoing ICSI treatment. It should be noted that in the present study the possible co-existence of other autoantibodies was not considered an exclusion criterion-unlike the study of Fan et al. (2017) [76] and, hence, it should be considered as a serious confounding factor.

In conclusion, ANAs presence is probably correlated with poor outcomes following IVF/ICSI cycles. The great majority of the studies are in line with the conclusion that ANAs positivity is correlated with lower clinical pregnancy rates and higher miscarriage rates. Further to that, studies indicate that ANAs could adversely affect oocyte quality and embryo development leading to infertility and possibly to immunologically induced RIF $[68,81]$. However, it should be mentioned that ANAs positivity was not only reported on infertile women population but also in fertile populations. Due to the fact that ANAs constitute a large group of different autoantibodies, future studies evaluating the 
effect of specific ANA types are required in order to provide guidance to the clinicians. There are insufficient data regarding the efficacy of adjuvant treatments for ANA positive women on IVF/ICSI outcome [10]. It should be highlighted, that studies included in this systematic review have enrolled populations of varying characteristics and diverse infertility etiologies. Thus, the level of heterogeneity among them is assessed as being considerably high. Further to that, the included studies herein, employed dissimilar cut-off levels and understandably employed varying laboratory methods in order to evaluate the autoantibodies profile. As a result, the strength of the provided evidence within the published literature is restricted. Robust data provided by future larger prospective studies and meta-analyses would provide more robust evidence in order to address the possible effects of the ANA in IVF/ICSI outcome. The future studies should include patients only with abnormal levels of specific ANAs excluding any other condition, while the control group should be infertile patients of good prognosis, while the primary outcome measure should be the live birth rate.

\section{Auto-Antibodies Specifically Affecting the Reproductive System}

There is a wide range of auto-antibodies that affect the reproductive system. A common cause of male infertility is the anti-sperm antibodies (ASA) that are present in the semen. ASA may be present in the follicular fluid but are not related to auto-immunity, thus female ASA were excluded from the present study. Auto-antibodies affecting the female reproductive system are anti-gonadotropin antibodies (AGA), anti-endometrial antibodies (AEA) and anti-laminin-1 (aLN1) antibodies present in the follicular fluid.

Nine studies were identified affecting the reproductive system and possibly altering the possibilities for a successful IVF cycle [82-90]. Four of the aforementioned studies concerned ASA [87,89-91], 3 AEA [83,86,88], one AGA [82] and one aLN1 in the follicular fluid of women with endometriosis [85]. Although ALN1 is not classified as a reproductive-specific antibody, the study population is diagnosed with endometriosis, a conditioned that has been associated to aLN1 [92]. Characteristics of the studies are presented in Table 4.

Two out of four studies regarding ASA were of retrospective nature, while the remaining two were prospective. Only two studies provided LB/OP data. The control group in one of those studies were oligoasthenoteratozoospermic (OAT) men. According to the study men with ASA had a better ICSI cycle outcome compared to OAT men [87]. Two studies reported results in clinical pregnancy [90,91]. The control groups were men without ASA. No statistically significant difference between the two groups was observed in either of the studies. A meta-analysis was performed on ASA [84] and the authors concluded that seminal ASA do not impede pregnancy possibilities. A limitation of that meta-analysis was the different cut-off points employed by the studies examined (ranging from $1 \%$ to $80 \%)$.

Regarding AEA, three studies were identified, all of them being of prospective nature. No study reported on LB/OP data. Two studies reported on clinical pregnancy. The study by Saparik and colleagues [86] investigated a possible correlation between the molecular weight of IgA, IgG, and pregnancy outcome. According to the results of that study, IVF outcome may be negatively correlated with certain subtypes of AEA. Examining another perspective, the presence of AEA in the sera of female patients may impede their fecundity and the success of an IUI cycle [83]. In all three groups (with endometriosis, without endometriosis, and without laparoscopic investigation) of the study, women diagnosed as AEA positive were associated with a lower $\mathrm{CP}$ rate. A second IUI cycle though increased the chances of $\mathrm{CP}$ up to five times. Only one study reported on miscarriage rate. According to Randall and colleagues [88] AEA positive was correlated with higher miscarriage rates. 
Table 4. Study characteristics regarding auto-antibodies affecting the reproductive system.

\begin{tabular}{|c|c|c|c|c|c|c|c|c|c|c|}
\hline \multirow[t]{2}{*}{ Studies } & \multirow[t]{2}{*}{ Type of Study } & \multirow{2}{*}{$\begin{array}{c}\text { Type of } \\
\text { Auto-Antibodies }\end{array}$} & \multirow[t]{2}{*}{ Study Group } & \multirow[t]{2}{*}{ Control Group } & \multicolumn{2}{|c|}{ Clinical Pregnancy Rate } & \multicolumn{2}{|c|}{$\begin{array}{l}\text { Live Birth/Ongoing } \\
\text { Pregnancy Rate }\end{array}$} & \multicolumn{2}{|c|}{ Miscarriage Rate } \\
\hline & & & & & Study Group & Control Group & $\begin{array}{l}\text { Study } \\
\text { Group }\end{array}$ & $\begin{array}{l}\text { Control } \\
\text { Group }\end{array}$ & $\begin{array}{l}\text { Study } \\
\text { Group }\end{array}$ & $\begin{array}{l}\text { Control } \\
\text { Group }\end{array}$ \\
\hline Rogenhofer et al., 2015 [82] & Case Report & - AGA & $\mathrm{n} / \mathrm{a}$ & $\mathrm{n} / \mathrm{a}$ & $\mathrm{n} / \mathrm{a}$ & $\mathrm{n} / \mathrm{a}$ & $\mathrm{n} / \mathrm{a}$ & $\mathrm{n} / \mathrm{a}$ & $\mathrm{n} / \mathrm{a}$ & $\mathrm{n} / \mathrm{a}$ \\
\hline Subit et al., 2011 [83] & Prospective & $-\mathrm{AEA}$ & $\begin{array}{c}\text {-AEA+ } \\
296 \text { Single IUI cycles } \\
105 \text { double IUI cycles }\end{array}$ & $\begin{array}{c}\text { AEA- } \\
673 \text { single IUI cycles } \\
169 \text { double IUI cycles }\end{array}$ & $\begin{array}{r}4.01 \% \\
14.29 \%\end{array}$ & $\begin{array}{l}13.07 \% \\
16.57 \%\end{array}$ & $\mathrm{n} / \mathrm{a}$ & $\mathrm{n} / \mathrm{a}$ & $\mathrm{n} / \mathrm{a}$ & $\mathrm{n} / \mathrm{a}$ \\
\hline Zini et al., 2011 [91] & Prospective & $-\mathrm{ASA}$ & $-26 \mathrm{ASA}(+) \mathrm{Men}$ & $-225 \mathrm{ASA}(-)$ Men & $42 \%$ & $52 \%$ & $\mathrm{n} / \mathrm{a}$ & $\mathrm{n} / \mathrm{a}$ & $\mathrm{n} / \mathrm{a}$ & $\mathrm{n} / \mathrm{a}$ \\
\hline Caccavo et al., 2011 [85] & Prospective & aLN-1 & $\begin{array}{l}-11 \text { aLN-1 positive women } \\
\text { with endometriosis }\end{array}$ & $\begin{array}{l}24 \text { aLN-1 negative women with } \\
\text { endometriosis }\end{array}$ & $\mathrm{n} / \mathrm{a}$ & $\mathrm{n} / \mathrm{a}$ & $36 \%$ & $29 \%$ & $\mathrm{n} / \mathrm{a}$ & $\mathrm{n} / \mathrm{a}$ \\
\hline Sarapik et al., 2010 [86] & Not provided & $-\mathrm{AEA}$ & -190 AEA positive women & $\mathrm{n} / \mathrm{a}$ & $\begin{array}{l}\text { OR: IgA: } 0.95 \\
\text { IgG: } 1.00^{a}\end{array}$ & $\mathrm{n} / \mathrm{a}$ & $\mathrm{n} / \mathrm{a}$ & $\mathrm{n} / \mathrm{a}$ & $\mathrm{n} / \mathrm{a}$ & $\mathrm{n} / \mathrm{a}$ \\
\hline Francavilla et al., 2009 [87] & Cross-Over & $-\mathrm{ASA}$ & -38 ASA positive men & -212 ASA negative OAT men & $\begin{array}{l}19 \% \text { (without } \mathrm{COH} \text { ) } \\
17.6 \% \text { (with } \mathrm{COH} \text { ) }\end{array}$ & $\begin{array}{l}2.9 \% \text { (without } \mathrm{COH} \text { ) } \\
6.4 \% \text { (with } \mathrm{COH}\end{array}$ & $\mathrm{n} / \mathrm{a}$ & $\mathrm{n} / \mathrm{a}$ & $\mathrm{n} / \mathrm{a}$ & $\mathrm{n} / \mathrm{a}$ \\
\hline Randall et al., 2009 [88] & Not provided & AEA & & & Not Provided ${ }^{b}$ & & & & & \\
\hline Van Weert et al., 2008 [89] & Prospective & ASA & -43 ASA positive men & -430 ASA negative men & $20.93 \%$ & $25.76 \%$ & $\mathrm{n} / \mathrm{a}$ & $\mathrm{n} / \mathrm{a}$ & $\mathrm{n} / \mathrm{a}$ & $\mathrm{n} / \mathrm{a}$ \\
\hline Esteves et al., 2007 [90] & Retrospective & $-\mathrm{ASA}$ & 17 men with $50 \%$ or more ASA & 301 men with $20 \%$ or less ASA & $47.06 \%$ & $53.16 \%$ & $\mathrm{n} / \mathrm{a}$ & $\mathrm{n} / \mathrm{a}$ & $25 \%$ & $17.94 \%$ \\
\hline
\end{tabular}

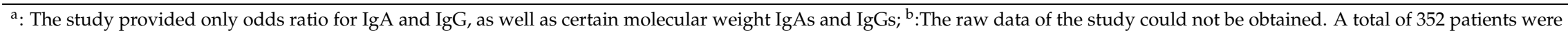
included and miscarriage was higher in the AEA positive group. 
A case report was presented regarding AGA [82]. The patient was diagnosed with resistant ovary syndrome and AGA. Despite the unfavorable prognosis of the male partner (OAT) the patient achieved a pregnancy that lead to a live birth. This case report validates the approach of ART for infertile patients with AGA. The impact of aLN1 in follicular fluids was explored in a prospective cohort study [85]. Women positive for aLN1 presented with similar ongoing pregnancy rate as women diagnosed as aLN1-negative [85]. This is in contrast to the other study performed by the same team regarding aLN1 in serum of women with Hashimoto Thyroiditis [23].

In conclusion, most auto-antibodies affecting the reproductive system do not exert a negative correlation to IVF cycles outcome. An exception to this, are the AEA that are associated with lower clinical pregnancy rates and higher miscarriage rates. It should be highlighted that the studies in the field present with great heterogeneity. Most of them employ different assisted reproduction techniques, as evident by the employment of IVF, ICSI, or IUI for patients with similar infertility factors. The control group employed in some studies are also poor prognosis IVF patients posing as another limitation. Furthermore, the study group is commonly affected by an additional disorder other than the autoimmune, serving as a confounder regarding the potential towards achieving a pregnancy. The conduction of better designed observational studies is a necessity for the advancement of this field. The future studies should include patients only with abnormal levels of auto-antibodies excluding any other condition, while the control group should be infertile patients of good prognosis, and the outcome measure should be live birth. Following the conduction of an adequate number of observational studies for each of the above-mentioned auto-antibodies, a possible meta-analysis may delineate their role in infertility and the outcome of an IVF cycle.

\section{Auto-Antibodies Related to Celiac Disease}

Celiac disease (CD) is a chronic inflammatory autoimmune disorder originating by an abnormal adaptive immune reaction against gluten-containing grains in susceptible people [93]. The pathophysiological mechanisms leading to the disease include several genetic and environmental factors, and thus CD is considered to be a multifactorial disease, Regarding the pathophysiological mechanism leading to the disease, the great majority of the studies demonstrate that in the $90 \%$ of the patients present specific genes encoding for major histocompatibility (MHC) class II proteins including the human leukocyte antigen (HLA)-DQ 2 and HLA-DQ8. Both HLA DQ 2 and HLA-DQ8 are co-expressed on antigen-presenting cells (APCs).

It is well documented that $\mathrm{CD}$, except from the classic gastrointestinal symptoms characterized the disorder, is also correlated with several pathological conditions such as type-1 diabetes, autoimmune thyroiditis, autoimmune hepatitis and other forms of liver involvement, neurological disorders and dermatitis herpetiformis [93]. In addition, recently published studies correlate CD with reproductive disorders and infertility in both males and females [94]. Regarding females, it is considered that $\mathrm{CD}$ affects the female reproductive system via several pathological mechanisms leading to delayed menarche, amenorrhea, earlier menopause, recurrent abortions, recurrent implantation failures, hypogonadism, and negative pregnancy outcomes [95]. In a recent meta-analysis published by Tersigni et al. (2014) [96] interestingly women suffering from unexplained infertility, recurrent miscarriage or intrauterine growth restriction (IUGR) were presented with a statistically significant higher risk of $\mathrm{CD}$ when compared to the general population. The higher prevalence of $\mathrm{CD}$ among the women experiencing unexplained infertility was also confirmed by other studies [97]. Further to that, in a recent meta-analysis published by Singh et al. (2016) [98], infertile women presented with a statistically significant higher risk of having CD in comparison to the general population Nonetheless, there are insufficient data regarding the direct impact of auto-antibodies related to CD on IVF/ICSI outcome.

Only one study, published by Juneau et al. (2018) [99], was considered suitable for inclusion in this systematic review, as only in this study the possible effect of auto-antibodies related to CD with regards to IVF outcome was investigated. In this prospective cohort study, 28 sero-positive for $\mathrm{CD}$ women were compared to 967 sero-negative for $\mathrm{CD}$ women. Celiac disease positivity was 
defined as elevated ( $>20 \mathrm{U} / \mathrm{mL}$ ) levels of tissue transglutaminase IgA (tTG) or/and endomysial IgA (EMA) antibodies. Out of the 28 sero-positive women, 18 women submitted to a single-blastocyst stage embryo transfer and out of 967 sero-negative women, 724 underwent an embryo transfer. No statistically significant difference could be established between the two groups regarding the number of normal fertilized zygotes, the blastulation rate, the positive pregnancy hCG test rate $(83.3 \% \mathrm{vs}$. $84.5 \%)$, the clinical pregnancy rate (50\% vs. $69 \%)$, the live birth rate $(50 \%$ vs. $68.1 \%)$ and the clinical pregnancy loss (27.8\% vs. $17.5 \%)$. Additionally, the patients' age, the hormonal profile (AMH levels), the number of oocytes retrieved and the number of transferred embryos did not differ significantly between the two groups. In the same study, authors employed a survey based on self-reports in order to investigate the possible effects of a gluten-free diet on IVF outcome, with gluten-free diet being to date the gold standard treatment for $\mathrm{CD}$. No statistically significant difference was observed between the two groups regarding the patients' dietary habits on IVF outcome. However, it should be highlighted that a significant number of the survey's participants stated that they had experienced a previous miscarriage (38.8\%) and suffer from menstrual irregularities $(28 \%)$. In addition, the great majority of the participants stated that their diet contained gluten $(91.4 \%)$. Authors, concluded that auto-antibodies related to CD did not impair IVF outcomes and the gluten-free diet did not present to have improved these outcomes. Despite the fact that this study in general could be characterized as well-designed, a number of serious limitations are identified. First of all, the sample size of the participants in the sero-positive for CD group was limited compared to the number of patients in the sero-negative group. A similar limited number of participants can be observed also in the group of patients stating that their diet was gluten-free (84 out of 987). In addition, authors employed per-protocol analysis in the sero-negative group, in contrast to the intention-to-treat analysis employed in the sero-positive group, regarding live birth rate. Furthermore, authors did not provide clear evidence regarding the distribution of the infertility etiologies among the study's groups. It should also be noted that in the present study the possible co-existence of other autoantibodies was not an exclusion criterion. For these reasons, conclusions regarding the direct impact of the auto-antibodies related to CD on IVF outcome in cannot be safely drawn with respect to the data provided from this study.

In conclusion, there is insufficient data regarding the impact of auto-antibodies related to CD on IVF/ICSI outcome, as only one study investigated this relationship to date. Data provided in this study indicates that, probably, the screening for celiac disease may not be viewed as requirement for infertile women in general. However, several other studies demonstrate a higher prevalence of $\mathrm{CD}$ in women suffering from menstrual irregularities, unexplained infertility, recurrent miscarriages, recurrent implantation failures and IUGR compared to the prevalence of $C D$ in the general population. These data indicate that auto-antibodies related to CD could adversely affect trophoblast invasion, finally leading to a poor placenta formation. Thus, a serologic screening for anti-endomysial and anti-TG antibodies may be suggested in such cases prior to IVF/ICSI treatment [97]. Robust data provided by future larger prospective studies and subsequent meta-analyses would provide more evidence in order to address the possible effects of the auto-antibodies related to CD on IVF/ICSI outcome. Future studies should include patients only with abnormal levels of anti-endomysial and anti-TG antibodies excluding any other condition, while the control group should consist of infertile patients of good prognosis, while the primary outcome measure should be the live birth rate.

\section{Conclusions}

In summary, while the effects of autoantibodies have been researched for many decades their effect on IVF cycle outcomes cannot yet be fully delineated. According to the literature search performed for this systematic review aPLs, TAA, and ASA do not seem to exert a negative outcome on IVF cycles regarding $\mathrm{LB} / \mathrm{OP}, \mathrm{CP}$, and $\mathrm{BP}$ rate. On the other hand, AEA and ANA present with lower $\mathrm{CP}$ rates, hence inducing a negative effect. This, is certainly heightening the need for further ART cycles and, hence, the possibility of IVF overuse should be investigated. 
It should be highlighted that most autoantibodies discussed, namely aPL, TAA, and ANA are associated with higher miscarriage rates. It may seem as a paradox that even though miscarriage rates are higher, there is no difference in live birth rates. This may be attributed to pure statistics. A possible explanation may be attempted in suggesting that the statistical significance is not reached due to sample size, while a possible pooling of the results may alter the outcome regarding LB/OP rates. The value that a meta-analysis may convey to the issue of delineating the role of autoantibodies in the spectrum of providing ART services would be considerable and, hence, it was investigated. The authors dismissed the idea of performing a meta-analysis as a number of the studies included herein have enrolled populations of varying characteristics and diverse infertility etiologies. Moreover, discrepant infertility treatment protocols have been employed thus increasing the covariates that must be accounted for. Another possible drawback is the different size both between the studies, as well as between the study and the control group employed within a study. Moreover, outcomes have been assessed differently by the numerous analyses employing varying approaches, adding to further confusion of the field. All of the above coupled by the fact that certain data originated form retrospective studies contributed to rendering a possible meta-analysis misleading.

To further our understanding and buttress current knowledge, conduction of well-designed prospective cohort studies is an absolute necessity in order to define the role of autoantibodies in the possibilities of IVF cycle success. A universal IVF treatment protocol, abiding to the proposed guidelines, as well as comparable laboratory techniques to evaluate the levels of autoantibodies should be employed. Blinding of personnel should also be considered by future research groups in order to enhance the robustness of the studies. Furthermore, a clear definition of the IVF outcome should be employed. Results should include only one cycle per patient and IVF outcome should be considered as clinical pregnancy and live birth rate or ongoing pregnancy-in case live birth reporting is not possible-per patient. The miscarriage rate should be reported per clinical pregnancy. Following the completion of such well-designed studies, future meta-analyses should be conducted in order to reach a final verdict regarding the role of autoantibodies in IVF cycle outcomes.

Supplementary Materials: Supplementary materials can be found at http:/ /www.mdpi.com/1422-0067/20/4/ 892/s1.

Funding: This research received no external funding.

Conflicts of Interest: The authors declare no conflict of interest.

\section{References}

1. Steptoe, P.C.; Edwards, R.G. Birth after the reimplantation of a human embryo. Lancet Lond. Engl. 1978, 2, 366. [CrossRef]

2. Palermo, G.; Joris, H.; Devroey, P.; Van Steirteghem, A.C. Pregnancies after intracytoplasmic injection of single spermatozoon into an oocyte. Lancet Lond. Engl. 1992, 340, 17-18. [CrossRef]

3. Simopoulou, M.; Sfakianoudis, K.; Maziotis, E.; Antoniou, N.; Rapani, A.; Anifandis, G.; Bakas, P.; Bolaris, S.; Pantou, A.; Pantos, K.; et al. Are computational applications the "crystal ball" in the IVF laboratory? The evolution from mathematics to artificial intelligence. J. Assist. Reprod. Genet. 2018, 35, 1545-1557. [CrossRef] [PubMed]

4. Lindsay, T.J.; Vitrikas, K.R. Evaluation and treatment of infertility. Am. Fam. Phys. 2015, 91, 308-314.

5. ESHRE ART Fact Sheet 2018. Available online: https://www.eshre.eu/Press-Room/Resources (accessed on 20 January 2019).

6. Simon, A.; Laufer, N. Assessment and treatment of repeated implantation failure (RIF). J. Assist. Reprod. Genet. 2012, 29, 1227-1239. [CrossRef] [PubMed]

7. Unuane, D.; Velkeniers, B.; Deridder, S.; Bravenboer, B.; Tournaye, H.; Brucker, M.D. Impact of thyroid autoimmunity on cumulative delivery rates in in vitro fertilization/intracytoplasmic sperm injection patients. Fertil. Steril. 2016, 106, 144-150. [CrossRef] [PubMed]

8. Cline, A.M.; Kutteh, W.H. Is there a role of autoimmunity in implantation failure after in-vitro fertilization? Curr. Opin. Obstet. Gynecol. 2009, 21, 291-295. [CrossRef] [PubMed] 
9. Zhong, Y.; Ying, Y.; Wu, H.; Zhou, C.; Xu, Y.; Wang, Q.; Li, J.; Shen, X.; Li, J. Relationship between Antithyroid Antibody and Pregnancy Outcome following in Vitro Fertilization and Embryo Transfer. Int. J. Med. Sci. 2012, 9, 121-125. [CrossRef] [PubMed]

10. Deroux, A.; Dumestre-Perard, C.; Dunand-Faure, C.; Bouillet, L.; Hoffmann, P. Female Infertility and Serum Auto-antibodies: A Systematic Review. Clin. Rev. Allergy Immunol. 2017, 53, 78-86. [CrossRef] [PubMed]

11. Chen, X.; Mo, M.-L.; Huang, C.-Y.; Diao, L.-H.; Li, G.-G.; Li, Y.-Y.; Lerner, A.; Shoenfeld, Y.; Zeng, Y. Association of serum autoantibodies with pregnancy outcome of patients undergoing first IVF/ICSI treatment: A prospective cohort study. J. Reprod. Immunol. 2017, 122, 14-20. [CrossRef] [PubMed]

12. Ferraretti, A.P.; Nygren, K.; Andersen, A.N.; de Mouzon, J.; Kupka, M.; Calhaz-Jorge, C.; Wyns, C.; Gianaroli, L.; Goossens, V. Trends over 15 years in ART in Europe: An analysis of 6 million cycles. Hum. Reprod. Open 2017, 2017. [CrossRef]

13. Braakhekke, M.; Kamphuis, E.I.; Dancet, E.A.; Mol, F.; van der Veen, F.; Mol, B.W. Ongoing pregnancy qualifies best as the primary outcome measure of choice in trials in reproductive medicine: An opinion paper. Fertil. Steril. 2014, 101, 1203-1204. [CrossRef] [PubMed]

14. Barnhart, K.T. Live Birth is the Correct Outcome for Clinical Trials Evaluating Therapy for the Infertile Couple. Fertil. Steril. 2014, 101, 1205-1208. [CrossRef]

15. Doufas, A.G.; Mastorakos, G. The hypothalamic-pituitary-thyroid axis and the female reproductive system. Ann. N. Y. Acad. Sci. 2000, 900, 65-76. [CrossRef]

16. Krassas, G.E.; Pontikides, N.; Kaltsas, T.; Papadopoulou, P.; Paunkovic, J.; Paunkovic, N.; Duntas, L.H. Disturbances of menstruation in hypothyroidism. Clin. Endocrinol. 1999, 50, 655-659. [CrossRef]

17. Krassas, G.E.; Pontikides, N.; Kaltsas, T.; Papadopoulou, P.; Batrinos, M. Menstrual disturbances in thyrotoxicosis. Clin. Endocrinol. 1994, 40, 641-644. [CrossRef]

18. Quintino-Moro, A.; Zantut-Wittmann, D.E.; Tambascia, M.; Machado, H.D.C.; Fernandes, A. High Prevalence of Infertility among Women with Graves' Disease and Hashimoto's Thyroiditis. Int. J. Endocrinol. 2014, 2014, 982705. [CrossRef] [PubMed]

19. Unuane, D.; Velkeniers, B.; Anckaert, E.; Schiettecatte, J.; Tournaye, H.; Haentjens, P.; Poppe, K. Thyroglobulin autoantibodies: Is there any added value in the detection of thyroid autoimmunity in women consulting for fertility treatment? Thyroid 2013, 23, 1022-1028. [CrossRef]

20. Poppe, K.; Glinoer, D.; Van Steirteghem, A.; Tournaye, H.; Devroey, P.; Schiettecatte, J.; Velkeniers, B. Thyroid dysfunction and autoimmunity in infertile women. Thyroid 2002, 12, 997-1001. [CrossRef]

21. Abalovich, M.; Mitelberg, L.; Allami, C.; Gutierrez, S.; Alcaraz, G.; Otero, P.; Levalle, O. Subclinical hypothyroidism and thyroid autoimmunity in women with infertility. Gynecol. Endocrinol. 2007, 23, 279-283. [CrossRef]

22. Alexander, E.K.; Pearce, E.N.; Brent, G.A.; Brown, R.S.; Chen, H.; Dosiou, C.; Grobman, W.A.; Laurberg, P.; Lazarus, J.H.; Mandel, S.J.; et al. 2017 Guidelines of the American Thyroid Association for the Diagnosis and Management of Thyroid Disease During Pregnancy and the Postpartum. Thyroid 2017, 27, 315-389. [CrossRef]

23. Caccavo, D.; Pellegrino, N.M.; Nardelli, C.; Vergine, S.; Leone, L.; Marolla, A.; Vacca, M.P.; Depalo, R. Anti-laminin-1 antibodies in serum and follicular fluid of women with Hashimoto's thyroiditis undergoing in vitro fertilization. Int. J. Immunopathol. Pharmacol. 2016, 29, 280-287. [CrossRef] [PubMed]

24. Chai, J.; Yeung, W.-Y.T.; Lee, C.-Y.V.; Li, H.-W.R.; Ho, P.-C.; Ng, H.-Y.E. Live birth rates following in vitro fertilization in women with thyroid autoimmunity and/or subclinical hypothyroidism. Clin. Endocrinol. 2014, 80, 122-127. [CrossRef] [PubMed]

25. Karacan, M.; Alwaeely, F.; Cebi, Z.; Berberoglugil, M.; Batukan, M.; Ulug, M.; Arvas, A.; Camlibel, T. Effect of antithyroid antibodies on ICSI outcome in antiphospholipid antibody-negative euthyroid women. Reprod. Biomed. Online 2013, 27, 376-380. [CrossRef] [PubMed]

26. Kilic, S.; Tasdemir, N.; Yilmaz, N.; Yuksel, B.; Gul, A.; Batioglu, S. The effect of anti-thyroid antibodies on endometrial volume, embryo grade and IVF outcome. Gynecol. Endocrinol. 2008, 24, 649-655. [CrossRef] [PubMed]

27. Lukaszuk, K.; Kunicki, M.; Kulwikowska, P.; Liss, J.; Pastuszek, E.; Jaszczolt, M.; Meczekalski, B.; Skowronski, K. The impact of the presence of antithyroid antibodies on pregnancy outcome following intracytoplasmatic sperm injection-ICSI and embryo transfer in women with normal thyreotropine levels. J. Endocrinol. Investig. 2015, 38, 1335-1343. [CrossRef] [PubMed] 
28. Magri, F.; Capelli, V.; Gaiti, M.; Brambilla, E.; Montesion, L.; Rotondi, M.; Spinillo, A.; Nappi, R.E.; Chiovato, L. Impaired outcome of controlled ovarian hyperstimulation in women with thyroid autoimmune disease. Thyroid 2013, 23, 1312-1318. [CrossRef]

29. Monteleone, P.; Parrini, D.; Faviana, P.; Carletti, E.; Casarosa, E.; Uccelli, A.; Cela, V.; Genazzani, A.R.; Artini, P.G. Female infertility related to thyroid autoimmunity: The ovarian follicle hypothesis. Am. J. Reprod. Immunol. 2011, 66, 108-114. [CrossRef]

30. Negro, R.; Formoso, G.; Coppola, L.; Presicce, G.; Mangieri, T.; Pezzarossa, A.; Dazzi, D. Euthyroid women with autoimmune disease undergoing assisted reproduction technologies: The role of autoimmunity and thyroid function. J. Endocrinol. Investig. 2007, 30,3-8. [CrossRef]

31. Revelli, A.; Casano, S.; Piane, L.D.; Grassi, G.; Gennarelli, G.; Guidetti, D.; Massobrio, M. A retrospective study on IVF outcome in euthyroid patients with anti-thyroid antibodies: Effects of levothyroxine, acetyl-salicylic acid and prednisolone adjuvant treatments. Reprod. Biol. Endocrinol. RBE 2009, 7, 137. [CrossRef]

32. Sakar, M.N.; Unal, A.; Atay, A.E.; Zebitay, A.G.; Verit, F.F.; Demir, S.; Turfan, M.; Omer, B. Is there an effect of thyroid autoimmunity on the outcomes of assisted reproduction? J. Obstet. Gynaecol. 2016, 36, 213-217. [CrossRef] [PubMed]

33. Tan, S.; Dieterle, S.; Pechlavanis, S.; Janssen, O.E.; Fuhrer, D. Thyroid autoantibodies per se do not impair intracytoplasmic sperm injection outcome in euthyroid healthy women. Eur. J. Endocrinol. 2014, 170, 495-500. [CrossRef]

34. Mintziori, G.; Goulis, D.G.; Gialamas, E.; Dosopoulos, K.; Zouzoulas, D.; Gitas, G.; Venetis, C.A.; Toulis, K.A.; Kolibianakis, E.M.; Tarlatzis, B.C. Association of TSH concentrations and thyroid autoimmunity with IVF outcome in women with TSH concentrations within normal adult range. Gynecol. Obstet. Investig. 2014, 77, 84-88. [CrossRef]

35. Toulis, K.A.; Goulis, D.G.; Venetis, C.A.; Kolibianakis, E.M.; Negro, R.; Tarlatzis, B.C.; Papadimas, I. Risk of spontaneous miscarriage in euthyroid women with thyroid autoimmunity undergoing IVF: A meta-analysis. Eur. J. Endocrinol. 2010, 162, 643-652. [CrossRef] [PubMed]

36. He, H.; Jing, S.; Gong, F.; Tan, Y.Q.; Lu, G.X.; Lin, G. Effect of thyroid autoimmunity per se on assisted reproduction treatment outcomes: A meta-analysis. Taiwan. J. Obstet. Gynecol. 2016, 55, 159-165. [CrossRef]

37. Busnelli, A.; Paffoni, A.; Fedele, L.; Somigliana, E. The impact of thyroid autoimmunity on IVF/ICSI outcome: A systematic review and meta-analysis. Hum. Reprod. Update 2016, 22, 775-790. [CrossRef] [PubMed]

38. Silver, R.M.; Parker, C.B.; Reddy, U.M.; Goldenberg, R.; Coustan, D.; Dudley, D.J.; Saade, G.R.; Stoll, B.; Koch, M.A.; Conway, D.; et al. Antiphospholipid Antibodies in Stillbirth. Obstet. Gynecol. 2013, 122, 641-657. [CrossRef] [PubMed]

39. Heilmann, L.; Schorsch, M.; Hahn, T.; Fareed, J. Antiphospholipid syndrome and pre-eclampsia. Semin. Thromb. Hemost. 2011, 37, 141-145. [CrossRef]

40. Di Prima, F.A.F.; Valenti, O.; Hyseni, E.; Giorgio, E.; Faraci, M.; Renda, E.; De Domenico, R.; Monte, S. Antiphospholipid Syndrome during pregnancy: The state of the art. J. Prenat. Med. 2011, 5, 41-53.

41. Andreoli, L.; Bertsias, G.K.; Agmon-Levin, N.; Brown, S.; Cervera, R.; Costedoat-Chalumeau, N.; Doria, A.; Fischer-Betz, R.; Forger, F.; Moraes-Fontes, M.F.; et al. EULAR recommendations for women's health and the management of family planning, assisted reproduction, pregnancy and menopause in patients with systemic lupus erythematosus and/or antiphospholipid syndrome. Ann. Rheum. Dis. 2017, 76, 476-485. [CrossRef]

42. Bellver, J.; Pellicer, A. Ovarian stimulation for ovulation induction and in vitro fertilization in patients with systemic lupus erythematosus and antiphospholipid syndrome. Fertil. Steril. 2009, 92, 1803-1810. [CrossRef]

43. Di Nisio, M.; Ponzano, A.; Tiboni, G.M.; Guglielmi, M.D.; Rutjes, A.W.S.; Porreca, E. Effects of multiple inherited and acquired thrombophilia on outcomes of in-vitro fertilization. Thromb. Res. 2018, 167, $26-31$. [CrossRef] [PubMed]

44. Hong, Y.H.; Kim, S.J.; Moon, K.Y.; Kim, S.K.; Jee, B.C.; Lee, W.D.; Kim, S.H. Impact of presence of antiphospholipid antibodies on in vitro fertilization outcome. Obstet. Gynecol. Sci. 2018, 61, 359-366. [CrossRef] [PubMed]

45. Andreeva, H.; Seip, M.; Koycheva, S. Live Birth Pregnancy Outcome after First In Vitro Fertilization Treatment in a Patient with Systemic Lupus Erythematosus and Isolated High Positive IgA Anti-beta2glycoprotein I Antibodies: A Case Report. Open Med. Wars. Pol. 2017, 12, 12-18. [CrossRef] [PubMed] 
46. Orquevaux, P.; Masseau, A.; Le Guern, V.; Gayet, V.; Vauthier, D.; Guettrot-Imbert, G.; Huong, D.L.T.; Wechsler, B.; Morel, N.; Cacoub, P.; et al. In Vitro Fertilization in 37 Women with Systemic Lupus Erythematosus or Antiphospholipid Syndrome: A Series of 97 Procedures. J. Rheumatol. 2017, 44, $613-618$. [CrossRef]

47. Paulmyer-Lacroix, O.; Despierres, L.; Courbiere, B.; Bardin, N. Antiphospholipid antibodies in women undergoing in vitro fertilization treatment: Clinical value of $\operatorname{IgA}$ anti-beta2glycoprotein I antibodies determination. BioMed Res. Int. 2014, 2014, 314704. [CrossRef] [PubMed]

48. DaCosta, V.; Chin, L.; Wynter, S.; Harriott, J.; Christie, L.; Frederick-Johnston, S.; Frederick, J.; McKenzie, C.; Everett, D.; Foster, R.; et al. Anticardiolipin antibodies and lupus anticoagulants among women undergoing in vitro fertilization in Jamaica. West Indian Med. J. 2012, 61, 789-794.

49. Ragab, A.; Barakat, R.; Ragheb, M.; State, O.; Badawy, A. Subfertility treatment in women with systemic lupus erythematosus. J. Obstet. Gynaecol. J. Inst. Obstet. Gynaecol. 2012, 32, 569-571. [CrossRef]

50. Ulcova-Gallova, Z. Repeated miscarriages in patients with antiphospholipid syndrome and subjected to in vitro fertilization: The importance of preimplantation genetic diagnosis. Lupus 2012, 21, 744-746. [CrossRef]

51. Ying, Y.; Zhong, Y.; Zhou, C.; Xu, Y.; Wang, Q.; Li, J.; Wu, H.; Shen, X. A retrospective study on IVF outcome in patients with anticardiolipin antibody: Effects of methylprednisolone plus low-dose aspirin adjuvant treatment. J. Reprod. Immunol. 2012, 94, 196-201. [CrossRef]

52. Zhong, Y.-P.; Ying, Y.; Wu, H.-T.; Zhou, C.-Q.; Xu, Y.-W.; Wang, Q.; Li, J.; Sheng, X.-T.; Li, J. Impact of anticardiolipin antibody on the outcome of in vitro fertilization and embryo transfer. Am. J. Reprod. Immunol. 2011, 66, 504-509. [CrossRef] [PubMed]

53. Lee, S.-R.; Park, E.-J.; Kim, S.-H.; Chae, H.; Kim, C.-H.; Kang, B.-M. Influence of antiphospholipid antibodies on pregnancy outcome in women undergoing in vitro fertilization and embryo transfer. Am. J. Reprod. Immunol. 2007, 57, 34-39. [CrossRef]

54. Sanmarco, M.; Bardin, N.; Camoin, L.; Beziane, A.; Dignat-George, F.; Gamerre, M.; Porcu, G. Antigenic profile, prevalence, and clinical significance of antiphospholipid antibodies in women referred for in vitro fertilization. Ann. N. Y. Acad. Sci. 2007, 1108, 457-465. [CrossRef] [PubMed]

55. Buckingham, K.L.; Stone, P.R.; Smith, J.F.; Chamley, L.W. Antiphospholipid antibodies in serum and follicular fluid-Is there a correlation with IVF implantation fare? Hum. Reprod. Oxf. Engl. 2006, 21, 728-734. [CrossRef] [PubMed]

56. Matsubayashi, H.; Sugi, T.; Arai, T.; Shida, M.; Kondo, A.; Suzuki, T.; Izumi, S.; McIntyre, J.A. IgG-antiphospholipid antibodies in follicular fluid of IVF-ET patients are related to low fertilization rate of their oocytes. Am. J. Reprod. Immunol. 2006, 55, 341-348. [CrossRef] [PubMed]

57. Matsubayashi, H.; Sugi, T.; Arai, T.; Shida, M.; Kondo, A.; Suzuki, T.; Izumi, S.-I.; McIntyre, J.A. Re: Antiphospholipid antibodies in serum and follicular fluid: Is there a correlation with IVF implantation failure? Hum. Reprod. Oxf. Engl. 2007, 22, 3043-3045. [CrossRef] [PubMed]

58. Deocharan, B.; Qing, X.; Beger, E.; Putterman, C. Antigenic triggers and molecular targets for anti-double-stranded DNA antibodies. Lupus 2002, 11, 865-871. [CrossRef]

59. Hahn, B.H. Antibodies to DNA. N. Engl. J. Med. 1998, 338, 1359-1368. [CrossRef]

60. Ahmed, N.; Shigidi, M.; Al Agib, A.N.; Abdelrahman, H.; Taha, E. Clinical features and antinuclear antibodies profile among adults with systemic lupus erythematosus and lupus nephritis: A cross-sectional study. Pan Afr. Med. J. 2017, 27, 114. [CrossRef]

61. Ehrenstein, M.R. Antinuclear antibodies and lupus: Causes and consequences. Rheumatology 1999, 38, 691-693. [CrossRef]

62. Fayyaz, A.; Kurien, B.T.; Scofield, H. Autoantibodies in Sjögren's Syndrome. Rheum. Dis. Clin. N. Am. 2016, 42, 419-434. [CrossRef] [PubMed]

63. Kuwana, M. Circulating Anti-Nuclear Antibodies in Systemic Sclerosis: Utility in Diagnosis and Disease Subsetting. J. Nippon Med. Sch. Nippon Ika Daigaku Zasshi 2017, 84, 56-63. [CrossRef] [PubMed]

64. Menor Almagro, R.; Rodríguez Gutiérrez, J.F.; Martín-Martínez, M.A.; Rodríguez Valls, M.J.; Aranda Valera, C.; de la Iglesia Salgado, J.L. Association between antinuclear antibody titers and connective tissue diseases in a Rheumatology Department. Reumatol. Clin. 2017, 13, 150-155. [CrossRef] [PubMed] 
65. Ravelli, A.; Felici, E.; Magni-Manzoni, S.; Pistorio, A.; Novarini, C.; Bozzola, E.; Viola, S.; Martini, A. Patients with antinuclear antibody-positive juvenile idiopathic arthritis constitute a homogeneous subgroup irrespective of the course of joint disease. Arthritis Rheum. 2005, 52, 826-832. [CrossRef] [PubMed]

66. Valentini, G.; Improta, R.D.; Resse, M.; Migliaresi, S.; Minucci, P.B.; Tirri, R.; Farzati, B.; Tirri, G. Antinuclear antibodies in first-degree relatives of patients with polymyositis-dermatomyositis: Analysis of the relationship with HLA haplotypes. Br. J. Rheumatol. 1991, 30, 429-432. [CrossRef] [PubMed]

67. Zachou, K.; Rigopoulou, E.; Dalekos, G.N. Autoantibodies and autoantigens in autoimmune hepatitis: Important tools in clinical practice and to study pathogenesis of the disease. J. Autoimmune Dis. 2004, 1, 2. [CrossRef] [PubMed]

68. Ying, Y.; Zhong, Y.; Zhou, C.; Xu, Y.; Wang, Q.; Li, J.; Shen, X.; Wu, H. Antinuclear antibodies predicts a poor IVF-ET outcome: Impaired egg and embryo development and reduced pregnancy rate. Immunol. Investig. 2012, 41, 458-468. [CrossRef] [PubMed]

69. Simerly, C.; Balczon, R.; Brinkley, B.R.; Schatten, G. Microinjected centromere [corrected] kinetochore antibodies interfere with chromosome movement in meiotic and mitotic mouse oocytes. J. Cell Biol. 1990, 111, 1491-1504. [CrossRef] [PubMed]

70. Alarcon-Segovia, D.; Ruiz-Argüelles, A.; Llorente, L. Broken dogma: Penetration of autoantibodies into living cells. Immunol. Today 1996, 17, 163-164. [PubMed]

71. Alarcon-Segovia, D.; Ruiz-Arguelles, A.; Fishbein, E. Antibody to nuclear ribonucleoprotein penetrates live human mononuclear cells through Fc receptors. Nature 1978, 271, 67-69. [CrossRef] [PubMed]

72. Yanase, K.; Madaio, M.P. Nuclear localizing anti-DNA antibodies enter cells via caveoli and modulate expression of caveolin and p53. J. Autoimmun. 2005, 24, 145-151. [CrossRef] [PubMed]

73. Parks, C.G.; Miller, F.W.; Satoh, M.; Chan, E.K.L.; Andrushchenko, Z.; Birnbaum, L.S.; Jusko, T.A.; Kissling, G.E.; Patel, M.D.; Rose, K.M.; et al. Reproductive and hormonal risk factors for antinuclear antibodies (ANA) in a representative sample of U.S. women. Cancer Epidemiol. Prev. Biomark. 2014, 23, 2492-2502. [CrossRef] [PubMed]

74. Reimand, K.; Talja, I.; Metsküla, K.; Kadastik, U.; Matt, K.; Uibo, R. Autoantibody studies of female patients with reproductive failure. J. Reprod. Immunol. 2001, 51, 167-176. [CrossRef]

75. Taylor, P.V.; Campbell, J.M.; Scott, J.S. Presence of autoantibodies in women with unexplained infertility. Am. J. Obstet. Gynecol. 1989, 161, 377-379. [CrossRef]

76. Fan, J.; Zhong, Y.; Chen, C. Impacts of Anti-dsDNA Antibody on In Vitro Fertilization-Embryo Transfer and Frozen-Thawed Embryo Transfer. J. Immunol. Res. 2017, 2017, 8596181. [CrossRef] [PubMed]

77. Li, Y.; Wang, Y.; Ma, Y.; Lan, Y.; Jia, C.; Liang, Y.; Wang, S. Investigation of the impact of antinuclear antibody on the outcome of in vitro fertilization/intracytoplasmic sperm injection treatment. Taiwan. J. Obstet. Gynecol. 2015, 54, 742-748. [CrossRef] [PubMed]

78. Ying, Y.; Zhong, Y.-P.; Zhou, C.-Q.; Xu, Y.-W.; Ding, C.-H.; Wang, Q.; Li, J.; Shen, X.-T. A further exploration of the impact of antinuclear antibodies on in vitro fertilization-embryo transfer outcome. Am. J. Reprod. Immunol. 2013, 70, 221-229. [CrossRef]

79. Ying, Y.; Zhong, Y.; Zhou, C.; Xu, Y.; Miao, B.; Wang, Q.; Li, J. Preliminary investigation of the impact of anticentromere antibody on oocyte maturation and embryo cleavage. Fertil. Steril. 2013, 100, 1585-1589. [CrossRef]

80. Zhu, Q.; Wu, L.; Xu, B.; Hu, M.-H.; Tong, X.-H.; Ji, J.-J.; Liu, Y.-S. A retrospective study on IVF/ICSI outcome in patients with anti-nuclear antibodies: The effects of prednisone plus low-dose aspirin adjuvant treatment. Reprod. Biol. Endocrinol. RBE 2013, 11, 98. [CrossRef]

81. Shirota, K.; Nagata, Y.; Honjou, K.; Tsujioka, H.; Yoshizato, T.; Miyamoto, S. Involvement of anticentromere antibody in interference with oocyte meiosis and embryo cleavage. Fertil. Steril. 2011, 95, 2729-2731. [CrossRef]

82. Rogenhofer, N.; Pavlik, R.; Jeschke, U.; Wypior, G.; Ochsenkuhn, R.; Thaler, C.J. Effective ovarian stimulation in a patient with resistant ovary syndrome and antigonadotrophin antibodies. Am. J. Reprod. Immunol. 2015, 73, 185-191. [CrossRef]

83. Subit, M.; Gantt, P.; Broce, M.; Seybold, D.J.; Randall, G. Endometriosis-associated infertility: Double intrauterine insemination improves fecundity in patients positive for antiendometrial antibodies. Am. J. Reprod. Immunol. 2011, 66, 100-107. [CrossRef] 
84. Zini, A.; Fahmy, N.; Belzile, E.; Ciampi, A.; Al-Hathal, N.; Kotb, A. Antisperm antibodies are not associated with pregnancy rates after IVF and ICSI: Systematic review and meta-analysis. Hum. Reprod. Oxf. Engl. 2011, 26, 1288-1295. [CrossRef]

85. Caccavo, D.; Pellegrino, N.M.; Totaro, I.; Vacca, M.P.; Selvaggi, L.; Depalo, R. Anti-laminin-1 antibodies in sera and follicular fluid of women with endometriosis undergoing in vitro fertilization. Int. J. Immunopathol. Pharmacol. 2011, 24, 481-488. [CrossRef]

86. Sarapik, A.; Haller-Kikkatalo, K.; Utt, M.; Teesalu, K.; Salumets, A.; Uibo, R. Serum anti-endometrial antibodies in infertile women-Potential risk factor for implantation failure. Am. J. Reprod. Immunol. 2010, 63, 349-357. [CrossRef]

87. Francavilla, F.; Sciarretta, F.; Sorgentone, S.; Necozione, S.; Santucci, R.; Barbonetti, A.; Francavilla, S. Intrauterine insemination with or without mild ovarian stimulation in couples with male subfertility due to oligo/astheno- and/or teratozoospermia or antisperm antibodies: A prospective cross-over trial. Fertil. Steril. 2009, 92, 1009-1011. [CrossRef]

88. Randall, G.W.; Bush, S., 2nd; Gantt, P.A. Serum and peritoneal fluid antiendometrial antibodies in assisted reproduction. J. Reprod. Med. 2009, 54, 353-360.

89. van Weert, J.-M.; Repping, S.; van der Steeg, J.W.; Steures, P.; van der Veen, F.; Mol, B.W. A prediction model for ongoing pregnancy after in vitro fertilization in couples with male subfertility. J. Reprod. Med. 2008, 53, 250-256.

90. Esteves, S.C.; Schneider, D.T.; Verza, S.J. Influence of antisperm antibodies in the semen on intracytoplasmic sperm injection outcome. Int. Braz. J. Urol. 2007, 33, 795-802. [CrossRef]

91. Zini, A.; Lefebvre, J.; Kornitzer, G.; Bissonnette, F.; Kadoch, I.J.; Dean, N.; Phillips, S. Anti-sperm antibody levels are not related to fertilization or pregnancy rates after IVF or IVF/ICSI. J. Reprod. Immunol. 2011, 88, 80-84. [CrossRef]

92. Inagaki, J.; Sugiura-Ogasawara, M.; Nomizu, M.; Nakatsuka, M.; Ikuta, K.; Suzuki, N.; Kaihara, K.; Kobayashi, K.; Yasuda, T.; Shoenfeld, Y.; et al. An association of IgG anti-laminin-1 autoantibodies with endometriosis in infertile patients. Hum. Reprod. 2003, 18, 544-549. [CrossRef]

93. McAllister, B.P.; Williams, E.; Clarke, K. A Comprehensive Review of Celiac Disease/Gluten-Sensitive Enteropathies. Clin. Rev. Allergy Immunol. 2018. [CrossRef]

94. Lasa, J.S.; Zubiaurre, I.; Soifer, L.O. Risk of infertility in patients with celiac disease: A meta-analysis of observational studies. Arq. Gastroenterol. 2014, 51, 144-150. [CrossRef]

95. Soni, S.; Badawy, S.Z.A. Celiac disease and its effect on human reproduction: A review. J. Reprod. Med. 2010, 55, 3-8.

96. Tersigni, C.; Castellani, R.; de Waure, C.; Fattorossi, A.; De Spirito, M.; Gasbarrini, A.; Scambia, G.; Di Simone, N. Celiac disease and reproductive disorders: Meta-analysis of epidemiologic associations and potential pathogenic mechanisms. Hum. Reprod. Update 2014, 20, 582-593. [CrossRef]

97. Vanciková, Z.; Chlumecký, V.; Sokol, D.; Horáková, D.; Hamsíková, E.; Fucíková, T.; Janatková, I.; Ulcová-Gallová, Z.; Stěpán, J.; Límanová, Z.; et al. The serologic screening for celiac disease in the general population (blood donors) and in some high-risk groups of adults (patients with autoimmune diseases, osteoporosis and infertility) in the Czech Republic. Folia Microbiol. 2002, 47, 753-758. [CrossRef]

98. Singh, P.; Arora, S.; Lal, S.; Strand, T.A.; Makharia, G.K. Celiac Disease in Women with Infertility: A Meta-Analysis. J. Clin. Gastroenterol. 2016, 50, 33-39. [CrossRef]

99. Juneau, C.R.; Franasiak, J.M.; Goodman, L.R.; Marin, D.; Scott, K.; Morin, S.J.; Neal, S.A.; Juneau, J.E.; Scott, R.T. Celiac disease is not more prevalent in patients undergoing in vitro fertilization and does not affect reproductive outcomes with or without treatment: A large prospective cohort study. Fertil. Steril. 2018, 110, 437-442. [CrossRef]

(C) 2019 by the authors. Licensee MDPI, Basel, Switzerland. This article is an open access article distributed under the terms and conditions of the Creative Commons Attribution (CC BY) license (http://creativecommons.org/licenses/by/4.0/). 